\title{
Elkanotar Juan Sebastian, Pizkundeko humanista utopikoa?
}

\author{
Juan Sebastian of Elkano: \\ An utopian humanist of the Renaissance?
}

EKAI TXAPARTEGI*\&

Filosofia saila (UPV/EHU)

\begin{abstract}
LABURPENA. Elkanotar Juan Sebastianen pentsamendu politikoa Pizkundeko humanista utopikoen artean lerrokatzea da artikulu honen ekarpen nagusia. Berak idatzitako bidaia-kronika galdu denez, eta iritsi zaizkigun eskutitz eta testigantzak urriegiak direnez, Elkanoren iritzi politikoak ezagutzeko Maximiliano Transilvano eta Gonzalo Fernandez de Oviedoren kroniketara jo behar dela erakusten saiatzen naiz. Bi kronika haietan gorde da, ziurrenik, Elkanoren idatzi galduaren berridazketa ia literala. Mundu-birari buruz Maximiliano Transilvano errege-idazkariak azkar batean idatzitako latinezko kronikaren bigarren zatia, esaterako, Elkanoren idatzi galduaren berehalako itzulpena dela ondorioztatzen dut artikuluan. Hipotesia zuzena bada, Transilvanoren kronikan Elkanoren irudimen utopikoa irakurtzen da, batik bat Borneoko herritarren ohiturak deskribatzen diren pasarte harrigarrian. Bertan, Elkano ahobizarrik gabe ariko litzateke, besteak beste, hedapen inperialen aurka, errege gerrazaleen aurka edo erlijio tolerantziaren alde. Pasarte horrek Elkano 'inperialaren' eraikuntza gaztelarra iraultzen du. Bat egiten du, ordea, Elkanori buruz ezagutzen ditugun datu guztiekin. Horrenbestez, norabide horretan ikertzen jarraitzea proposatzen dut.
\end{abstract}

GAKO-HITZAK: Elkano; Juan Sebastian; Pizkundea; humanismo utopikoa; Maximiliano Transilvano; Gonzalo Fernandez de Oviedo; lehen mundu-bira; Borneo.

\begin{abstract}
The main goal of this article is to argue that the political thought of Juan Sebastian Elkano lines up with the utopian humanists of the Renaissance. Given that his written report of the circumnavigation is lost, and his letters and received testimonies are too scarce, I maintain that to access to his political opinions we should resort to the Chronicles of Maximilianus Transylvanus and Gonzalo Fernandez de Oviedo. Most certainly, those two Chronicles of the circumnavigation bear an almost literal transcription of his lost written account. I conclude that the Chronicle that Transylvanus rushed to write in Latin, for instance, is a hasty translation of Elkano's report. If this hypothesis is correct, that Chronicle contains the utopian imagination of Elkano, particularly in the astounding paragraphs where he describes the political and religious practices of the people of Borneo. There, Elkano would be expressing his opposition to imperialist expansions or bellicose kings, and his sympathies for religious tolerance, without mincing his words. This hypothesis suits every known data about him, while casting down the Castilian construction of 'imperial' Del Cano. Therefore, I propose to continue doing research in this direction.
\end{abstract}

KEYWORDS: Elcano; Juan Sebastian; Renaissance; utopian humanism; Maximilianus Transylvanus; Gonzalo Fernández de Oviedo; circumnavigation; Borneo.

\footnotetext{
\& Aitortza berezia merezi du Enrique Santamaria euskal idazleak, Transilvanok sinatutako kronikaren bigarren zatiak Elkanoren idatzia jasotzen duelako hipotesia/aurkikuntza berari zor zaiolako. Eskertu nahi ditut baita ere GOGOA aldizkariko iruzkingileak, artikulua hobetzeagatik. Elkano 500 Fundazioari ere eskerrak, Juan Sebastian ezagutzera emateko ahalegin eta laguntza guztiengatik. Lan honek UPV/EHUko Ikerketa Errektoreordetzaren laguntza jaso du (PPGA19/23), eta Eusko Jaurlaritzako Hezkuntza Sailarena (IT1205-19).
}

\footnotetext{
* Harremanetan jartzeko / Corresponding author: Ekai Txapartegi. Tolosa Hiribidea, 70 (20018 Donostia) - ekai.txapartegi@ ehu.eus - https://orcid.org/0000-0002-9152-6563

Nola aipatu / How to cite: Txapartegi, Ekai (2020). «Elkanotar Juan Sebastian, Pizkundeko humanista utopikoa?», Gogoa, 21, 61-99. (https://doi.org/10.1387/gogoa.22118).
}

Jasoa: 2020-I-27. Onartua: 2020-X-5. Aurrena online argitaratua: 2020-X-7.

ISSN 1577-9424 - eISSN 2444-3573 / (c) 2020 UPV/EHU

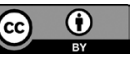

Lan hau Creative Commons Aitortu 4.0 Nazioartekoaren

lizentziapean dago 
Del Canori buruz idatzi da, ez Juan Sebastiani buruz. Pertsonaiari buruz, ez pertsonari buruz. ${ }^{1}$ Inperio-konkistatzailearen morroi leial eta konbentzituaren interpretazio-marko orokortu eta onartu hori, pertsonaia hori, zalantzan jartzea da idatzi honen asmoa. Horretarako, esku-eskura ditugun ebidentzia sendoenetan oinarrituko naiz: Elkanoren biografia eta hark hartutako hainbat erabaki; bere eskuz idatzita iritsi zaizkigun dokumentu bakanak, bi gutun eta hilburukoa; eta, batez ere, Elkanok idatzitako mundu-biraren kontakizun hartatik Maximiliano Transilvanok eta Gonzalo Fernandez de Oviedok ustez berridatzitako pasarteak. Elkanoren kontakizun hura galdu denez, bi berridazketa horiek izan litezke bere pentsaera politikoa asmatzen hasteko eskura ditugun ebidentzia sendoenak. Artikulu honen hipotesi nagusia hori da, hain zuzen, bi berridazketa horietan egiten den Borneo uharteko deskribapen utopikoan arreta jarrita, Elkano humanista irakur dezakegula, errotik auzitan jartzen dituena monarkia gerrazalea, inperioaren zabalkunde-asmoa eta kristau-fedearen inposaketa. Ondorioz, gero eta nabariagoa izango da, nire iritziz, militar inperiozalearen ezaugarritze faltsua atzean utzi eta beste interpretazio-marko emankorragoa eta egiazkoagoa irekitzeko beharra: Pizkundeko humanista kritikoekin bat lerrokatutako marinelarena.

Ez nuke iradoki nahi Elkanoren idatzia, intelektualki, Rotterdamgo Erasmok edo Tomas Morok idatzitako liburuen parekoa denik. Baina loturak nabariak dira. Utopia humanista haien atzean «aurkikuntza kolonbinoak» daude (Ramos 1990), hain zuzen, ohikoa zelako aurkikuntzen kronikak deskribapen utopikoz apaintzea: «abiatu aurretik amestutakoak uharte bakoitzean aurkitu zituztela usteko zuten marinel guztiek».2 Elkano gutxietsi egiten duen Angleriak ez du haren utopia jaso bere kontakizunean, baina ia 30 urte lehenago jaso zuen Kolonena, non amerikarrak 'urrezko arokoak' direla esaten den (Década I, III. liburua, VIII. kapitulua). Ez da harritzekoa, beraz, Elkanok idatzitako bidaia-kronikan ere marinelaren utopiek bere tokia aurkitzea. Horregatik, Transilvanoren eta Fernandez de Oviedoren kroniketan El-

\footnotetext{
1 «[Laurgainen agertutakoak] dokumentu administratiboak dira, baina arretaz irakurrita eta xehetasunez aztertuta Elkanori buruz datu asko emango dizkigute. Bere kezka eta interesei buruz. Pertsonari buruz, pertsonaiari buruz baino gehiago. Zeina, bide batez esateko, marinelak erakusten duen ikuspegi interesgarriena den, orain arte landu ez delako edo, zehatzagoak izateko, historiografia klasikoaren interesetik kanpo geratu delako orain arte. Bere balentria planetarioari buruz zerbait badakigu; gutxi dakigu, ordea, Elkano nor izan zen.» (Aguinalde 2017: 66) («Se trata de documentos [Laurgainen agertutakoak] que podríamos denominar como administrativos, pero cuya atenta lectura y análisis pormenorizado nos van a proporcionar muchos datos sobre Elcano, sus preocupaciones e intereses. Sobre la persona, más que sobre el personaje. Que, por cierto, es la perspectiva desde la que más interesante se nos muestra el marino, además de ser completamente inédita o, más bien, ajena hasta la fecha a los intereses de la historiografía clásica. Algo sabemos de su gesta planetaria, poco sobre quién era Elcano.») [Besterik esan ezean, erdarazko aipuen euskarazko itzulpenak egilearenak dira.]

2 «Todo navegante creía encontrar en cada isla algo con lo que soñó antes de emprender la aventura.» (Ramos 1990: 28)
} 
kanorena iritsi bazaigu estalita, hipotesi hori zuzena bada, bere pentsamendu politikoa marrazten hasteko atea zabaldu zaigu.

\section{Del Cano ala Elkano?}

1522, gizakiak estreinakoz besarkatu du lurra bere gerri-buelta osoan. ${ }^{3}$ Itsasotik itsasora hiru urtez txalupatxo zulatuetan arrastaka ibilita, Elkano eta beste 17 marinelek beso-zabalik mundua inguratu eta lehen estutua eman diote. ${ }^{4}$ Errelato hori, erraldoia, gertakari soila baino gehiago dena, gizadiaren eskalakoa, euskaldunontzat ia bakarra, nor ari da idazten?

Elkarri mokoka, Espainiako erakunde inperiozaleak, batetik, eta herri-mugimendu inperio-arrotza, bestetik. Kontrajarrita itxuraz. Del Cano (Fernández de Navarrete 1872) zaleei Gaztelako militar leiala gustatzen zaie. Elkanoren aurkariei, ${ }^{5}$ berriz, hori da, hain zuzen, gustatzen ez zaiena, Gaztelako militar inperialistari gorazarre egitea. Kontakizun faltsu eta interesatu berean harrapatuta jarraitzen dute, ordea, biek. Bi aukera, baina sakonean berdinak, batak zuriz besteak beltzez baina Elkano inperial ${ }^{6}$ bera margotzen dutelako biek.

3 «Bidaldi hau, beraz, Lurraren biribiltasunaz egindako lehen egiaztapena izan zan». Esaldia Joan Inazio Goikoetxea 'Gaztelu' olerkilariarena da, Manuel Elorzaren «Juan Sebastian de Elcano» biografia laburra euskaratzean idatzia. Gazteluren euskara ederragatik merezi du biografia labur hori irakurtzea.

${ }^{4}$ Zorrotzak izanda, Guinea Bisau edo Senegalgo kostalde parean ixten da mundu-bira. Handik igaro ziren bost ontziak 1519ko urrian, mendebalderantz hartu aurretik, eta handik ere itzuli Victoria 1522ko uztailean, Cabo Verden porturatu baino egun batzuk lehenago. Beraz, eta zorrotzak izanda, bi urte eta bederatzi hilabete ondoren, 35 bat lagunek puntu horretan lortu zuten munduari bira osoa segida bakarrean ematea.

Bi kolpetan egindako mundu-bira, agian, Malasiara iristean jada lortu zuten Magallaesen bi esklabuek (Fernandez de Oviedo 2011 [1535]: XX. liburua, 1 kapitulua, 15 orria), Malasia-Lisboa (1511an) eta Sevilla-Malasia (1519tik 1521ra) bi bidaiak puntu geografikoren batean teilakatu zirela suposatzen bada.

5 www.elkanoribira.eus

6 'Inperial' izenordea egokia da, Pagden irmoa den arren, inperioa ukatzen duenean: «Espainiar inperiorik ez da sekula izan, ez izenez ez izanez» (Pagden 2014: 30) («There never was, in either name or fact, a Spanish empire»). Garai hartan, XVI. eta XVII. mendeetan, baina bereziki Karlos V.aren monarkia garaian, erreinua konglomeratua zen, inperioa baino gehiago, Estatu forma bateratura iristeko saiakerarik ez zelako oraindik egin, eta ia independente funtzionatzen zuten erreinuen federazioen antza zuelako. Hala ere, 'inperio' hitza erabiltzen jarraituko dut behar denean, Muthuk egiten duen modu zabal eta ohiko horretan: «'Inperio' edo 'inperialismo' terminoak zentzu zabalean erabiltzen ditut, jendarte batek bestea formalki edo informalki arautzeko gaitasuna duela esateko, batez ere (baina ez soilik) metropolia eta lurralde kolonizatuen arteko distantzia handia denean, Europako gobernu inperialek ez-europarren gainean izan zuten agintea bezala» (Muthu 2003: 285) («I use the terms 'empire' and 'imperialism' in a broad sense to indicate either the formal or the informal rule of one society over another society, especially (but not only) those cases when the metropole and the colonized territories are distant, such as European imperial rule over the non-European peoples»). 
Izan ere, zer, Juan Sebastian Elkanotarra beste norbait izan bada? Marinel-merkatari fidagarria, gehienetan esaneko agian, batzuetan errebelde, moralki ez bereziki heroiko, politikoki ez inperialista, baina aparteko nabigazio eta lidergo abileziengatik garaiko indar ekonomiko eta politiko nagusiek misio suizida ${ }^{7}$ baterako fitxatu zutena eta handik bizirik eta garaile ateratzea lortu zuena. Zergatik ez?

Elkano garaiarekin eta inperioarekin mimetizatuta irudikatzen dugu. Baina hori ere agian gure sinplifikazioa da. Artikulu honetan zehar agerian jartzen saiatuko naiz, gaur-gaurkoz eskura ditugun jatorrizko testu-ebidentzia sendoenek hipotesi eraberritzailea hauspotzen dutela: Elkano europar Pizkundeko humanista kritikoen artean kokatzen duena. Saiatuko naiz argudiatzen, gutxien-gutxienez merezi duela norabide horretan ikertzen hastea, atzean utzita XIX. mendean nazionalismo espainiarrak asmatutako Del Cano konkistatzailearen pertsonaia hura.

\subsection{Gutxi dakigu}

Ziur-ziur hauxe bakarrik: muturreko abentura hura egiteko behar adina gaitasun biltzen zituela eta, beraz, aparta zela laguna, gutxi bezalako kapitain fenomenala. Kapitain gisa Moluketatik Cabo Verdera bitarteko infernua pasatu behar da, egunean 24 aldiz ura ponpatu behar zaion ontzi matxuratuan harrapatuta, ${ }^{8}$ lur-hartu gabe bost hilabetean, inoiz inork nabigatu gabeko olatuen kontra, lurmuturreko haizea kontra, eta hildakoak pilatzen ari zaizkiola. ${ }^{9}$ Parte hori behintzat txapela eranztekoa da, ontzi-nabigazioaren historiako gailurretakoa.

\footnotetext{
7 'Suizida' esatea ez da gehiegi esatea. Garai hartako ozeanoarteko espedizioetan ohikoa zen eskifaiaren herena ez itzultzea (Greengrass 2015: 200). Moluketako saioan, gainera, Diaz de Solisen aurrekaria zegoen, 1516an Brasilen hil zituztenak. Horregatik, Magallaesek ia bi urtez luzatu zituen prestaketak, besteak beste zailtasunak zituztelako marinelak topatzen. Elkano ibili zen buru-belarri marinel bila, ontzi-maisu gisa zeregin hori berari zegokiolako. Inguruko marinelak jakitun ziren bidaia horren muturreko arriskuaz, bi urteko bidaia espero zutelako gutxienez inoiz inork igaro gabeko itsasbide berrietatik barrena. Eta Elkano 'fitxatu' zutela ere nahiko nabaria da, maisu izendatu baitzuten, ardura handiko postua lege-zorrak zituen norbaitentzako.

8 Ayamontek (1522) ematen du datu hori: «Timorerantz abiatu zenean, ontziko ponpari hamabi aldiz ematen zitzaion egunez, eta hamabi aldiz gauez» («Y la nao, cuando partió de Timor, daba a la bomba doce veces de día y doce veces de noche»). 'Broma' izeneko moluskuak egindako zulotxoetatik sartzen zitzaien ura ontzira.

9 Pigafettaren (2019 [1522]) datazioa jarraitzen badugu, Tidore uhartetik 1521eko abenduaren 21ean ontziratu ziren, 60 lagun, 47 europar eta 13 asiar. Otsailera arte geldialdiak egin zituzten bideko hainbat uhartetan. Otsailaren 11n Timor uhartetik abiatu ziren eta uztailaren 9ra arte, bost hilabete luzez, ez zuten lurrik zapaldu. Nabigazio horren bi hilabetetan, maiatza-ekaina, 21 lagun hil zitzaizkien ontzian, muturreko ahultasunak eragindako gaixotasunengatik. Cabo Verdera 34 lagun bakarrik iritsi ziren.
} 
Hortik aurrera, Elkanori buruz ziurtasunez hitz egitea ausarkeria da. Behin arakatzen hasita, gainera, apaltzen ere hasten gara, ziur-ziur bere adina ere ez dakigulako, hortik hasita. Historiagile canovistek eta frankistek Elkanori bizkarreratu ohi dioten curriculum konkistatzailea izateko itsasoratzean 42 urte inguru behar zituen. Elkanok berak gezurtatzen du datua, ordea, itsasoratzean 32 urte zituela dioenean (Bernal 2019b: 12). Konkretuki, Cisnerosekin militar aritu zela ere baieztatzen da behin eta berriz, mairuen aurkako Orango konkistan (1509). Baina hori ere apaindura inperial berantiarra da, eusteko froga erabakigarririk gabe ziurtatzen dutena. Jakin badakiguna kontrakoa da, Orango ontzien zerrendan bere ontzia ez dela ageri; ez eta kapitain, ontzi-jabe edo maisu izenen artean «Del Cano», «El Cano», «Cano» edo antzekorik.

Del Cano edo Elcano inperiala XIX. mendeko historiagile hispanisten asmakuntza izan da; historia egileena, ez historialariena. Historia egile inperiozaleena, zehatzak izateko. Ziurtzat ematen dugun errelatoa Espainiako eliteetatik jasotzen dugu, harrokeria inperialistaren forman, XIX. mendean bezala oraindik ere ez daukaten nazio-sorkuntzan jarraitzen dutelako tai gabe, historiagintza ere horretarako baliatuz. Del Canoren kasuan, biografo nagusiak izan dira, besteak beste, Martin Fernandez de Navarrete, Eustaquio Fernandez de Navarrete eta Amando Melón Ruiz de Gordejuela. Inperio espainolaren iragan loriatsua erreskatatzera datorren historiagile nazionalista horiei, ordea, zergatik sinetsi? Eta haien kontakizunak amuz josita badatoz?

\subsection{XVI. mendea beste mundu bat zen}

'Del Cano konkistatzailea: loriatu edo baztertu?' eztabaida-markoan jarraitzen dugun bitartean, galdera berriak, galdera normalenak egiteko aukera galtzen jarraitzen dugu. Esaterako, Juan edo Sebas, nola deitzen zuten gertukoenek Elkano? Ez dakigu. Edo zein konfidentzia egiten zizkien lagunei? Nola maitatzen zuen, umorerik bazuen... gustura jakingo genituzke, baina horiek ere asmatu egin behar.

Eta ezagutu nahi ditugun kategoriak gure garaikoak direnean, «abertzalea ote zen?», «ezkertiarra?» galderek zentzua galtzen dute eta analogien eremura irristatzen gara, bi mundu hain aparteko konparatzeko. Tentuz ibili bakarrik ez, testuinguruak bereiziz jokatu behar da.

Artean ez zen oraindik Espainia existitzen, Estaturik ere ez, ez behintzat guk ulertzen ditugun moduan. ${ }^{10}$ Mundu-birako ontziak Sevillatik atera ziren

10 Espainiak «las Españas» bai, ordea, hori zen Erregeen titulua XIX. mendean ere. Isabel II.a «Reina de las Españas». Gaztelak Espainiar penintsularen izena bereganatu zuen eta, Erresuma konposatua izan arren, Europan erresuma guztiak «konposatuak» zirelako, Erresuma izan bazen. 
1519 hartan izango ziren 500 bat entitate politiko subirano Europan (Greengrass 2015 [2013]: 304). Gainera, erregeen lehen eginkizuna ezkontza edo herentzia bidez euren jabegopean eroritako herrien 'eskubide' eta 'erregaliak' babestea zenez, herrialde bakoitzeko noblezia, legeak (foruak) eta ohiturak errespetatu eta errespetarazi behar zituzten, eginkizun hori koroarekin bat zetorrelako. ${ }^{11}$ Erreinu beraren baitako subiranotasun-lokalak errespetatzeko auzian, ordea, Juan Bodino legelariak bereizi egiten zituen, eta mailakatu, pareko erreinuak (aeque principaliter), eta konkistatuak edo kolonizatuak (Greengrass 2015 [2013]: 309). Praktikan ere bereizi eta mailakatu egiten zirelako lehenak (errespetatzen direnak) eta bigarrenak (errespetatzen ez direnak). ${ }^{12}$ Bereizketa horren ondorioz etorri zen, esaterako, lurralde konkistatuek ezkutatu nahi zutela iraganean izandako porrot militarra, bigarren kategorian ez erortzeko. Gipuzkoak nabarmen, zeinak behin eta berriz ukatu zuen XIII. mendean Gaztelak konkistatu izana, borondatezko bateratze kondairaren mesedetan. Erreinu guztiek 'pareko' izan nahi zuten erregearen aurrean.

Kasurako, Gaztelan tokatutako errege inperiala alemana zen, Karlos V.a zesarra, gaztelania traketsa zerabilena kultura flandriarra zekarrelako. Bere ama Joana 'Eroa'ren itxialdia baliatuz, haren lurrak erreklamatzera iritsi berria, 16 urteko nerabea oraindik, berehala 1518an sutan jarri zituen gaztelarrak, gaztelania ulertzen ez zuelako, administrazioa alemanez eta borgoinarrez josi zietelako eta Alemaniako zor itzelak Gaztelaren bizkar ordaintzeko beldur zirelako. 27 erreinu heredatu arren, Karlos V.a agintari hedatzailea zen, garai hartako gehienen modura, kristandadearen hondarretan oraindik ere monarchia universalis amesten jarraitzen zuen azkenetarikoa. Nafarroako Erreinu konkistatu berriaren erresistentzia printzak sustraitik erauzteaz gain, Mexiko, Tarascon, Yucatan, Guatemala, Peru, Kolonbia eta Txilera zabaldu zuen inperioa.

Inperioa zen, konkistatzaileen inperio bihozgabea. Gaztelarrek indigenak modu sadiko gordinenetan nola garbitzen zituzten irakurri diogu Bartolome de las Casasi (1999 [1522]), zakur-bazka eta su-moteletan, baina era berean

\footnotetext{
«Konposatu» kontzeptua XVIII. mendean legelari «austrazistek» erabiltzen zutena zen eta 1974tik akademikoki egokiena irizten zaiona. Bizkaiko Batzar Nagusietako legelari Loyzagak, XIX. mendean erabiltzen zuen «konposatu» kontzeptua, Batzar Nagusien aginteak bermatzeko. Eskerrak eman nahi dizkiot txostengile anonimoetako bati iruzkin honegatik.

11 «Aginte dinastikoa kontserbadorea zen berez. Agintari legitimoak ez zuen soilik gobernatzeko eskubidea aldarrikatzen, bere herrien 'eskubide' eta 'pribilegioak' zaintzera ere konprometitzen zen.» (Greengrass 2015 (2013): 321) («El dominio dinástico era intrínsecamente conservador. Un gobernante legítimo no solo reclamaba el derecho a gobernar, sino también a preservar los 'derechos' y 'privilegios' de sus pueblos.»).

12 Aurrerago, Salamankako Eskolako Juan de Solorzano Pereirak modu sakonagoan landu zuen bereizketa hori Política Indiana liburuan (1647), Amerikar kolonietan ikusitakoan oinarrituta.
} 
ezaguna da urte haietantxe (1527) Erroma sakratua ere arpilatu zutela, eta bertako emakume errenazentistak bortxatu zituztela zientoka, kristauak, zuriak eta europarrak izanik ere. ${ }^{13}$ Ez zegoen 'indioa' izan beharrik norbera animalia basatitzat tratatua izateko. Eta aita santua, aita santu ukiezina, hilabete luzetan hartu zutela atxilo, Clemente zazpigarrena, medicitarra, Europako familia loriatsuenekoa. Inperioak ez du hertsadura moralik errespetatzen, bere bidean doa beti gehiagoren bila: boterea-lurrak-aberastasunak. Hertsadura moralik gabe ekiten du hedatze-asmoak hala eskatzen duenean.

Txakolinez omentzen dugu Elkano, garai gupidagabe hartakoa. Pelikulak egiten ditugu eta eskoletan erreferentziatzat darabilgu, baina Karlos V.aren baimenarekin/aginduz abiatu zen Moluketara. Konkistatzaile inperialista beraz? Abenturazale jatorra? Edo beste zerbait?

\subsection{Zein da gure errelatoa?}

Bada errelato nagusi bat europarra, Stefan Zweig idazleak Magallaes liburuan (1938) esaldi bakarrean laburtzen duena: «Lurraren esplorazio-historiako lorpenik handiena». ${ }^{14}$ Europar Batasunak atzera begiratu nahi du, zalantzan dagoen batasun europar hura berregiteko oinarri bila. Bidaia harekin erakutsi nahi du abentura zoroenak lagundu zuela aro argitsuena erditzen. Munduari bira ematean, lorpenaz liluratuta, batu egin zela Europa sineskeria faltsuen aurka, erlijio-dogmen aurka, bizitzeko modu tradizionalen aurka, hierarkia naturalen, muga hertsien eta intolerantziaren aurka. Eta oinarrietan batuta jarraitu zuela Europak, barne liskarrak liskar, atzean uzteko Erdi Aroa, eta ekartzeko zientzia, merkataritza, industrializazioa, liberalismoa eta demokrazia. Hori da Europar Batasunetik bultzatu nahi den errelatoa.

Eta errelato horren muina, Zweigek zioen itsas egitasmo gogoangarrienarena, ederra da. Zalantzarik gabe, kontatzeko istorio ederretan ederrena delako, bai gertakariaren epikotasunagatik bai eta garai hartan izan zuen eragin kulturalagatik. Munduari itzulia ematea, ez da makala marinel haiek egindakoa. Txalupatxoetan, urik gabe askotan, jatekorik gabe astetan, atsedenerako porturik gabe, lagun bakar haizea izanda, dabilenean, bestela geldi,

13 Batez ere mojak bortxatu zituzten Erroman, baina baita etxetik ateraraztea lortzen zutenak ere. Pizkunde garaiko emakume italiar peto-petoak. Horrela kontatu zuen Francesco Guicciardinik 10 urte beranduago idatzitako Italiako historian: «Erromako emazte eta mojen aiene eta garrasiak entzun ziren, lizunkeria-gosea asetzeko soldaduek saldoka zeramatzatenean: hilkorrenganako Jainkoaren epaia iluna dela soilik esan liteke, emakume erromatarren kastitate ezaguna indarrez erauzia izan baitzen» (Guicciardini 1537) («Sentivansi i gridi e urla miserabili delle donne romane e delle monache, condotte a torme da' soldati per saziare la loro libidine: non potendo se non dirsi essere oscuri a' mortali i giudizi di Dio, che comportasse che la castità famosa delle donne romane cadesse per forza in tanta bruttezza e miseria»).

14 «das Grossartigste geleistet in der Geschichte der Erderkundung.» (Zweig 1938) 
eta alimaleko ekaitz eta olatuak etsai... munduari bira osoa ematea. Hiru urtez etxetik urrun, literalki beste puntan nabigatzen, itsaso zabalenetan izarrei begira erdi-galduta, edo arroka ikusezinen arteko pasabide estuetan bestela, bihar zer jakin gabe eta... mirakuluz etxera bizirik itzultzea. Egin egin behar da.

Gutxitan du 'epikoa' izenlagunak hain helduleku aproposa. Haien hotzak, haien goseak, haien nekeak. Zalantzarik gabe gure errelato nazionalaren parte izan beharko luke. Elkanori arreta jarrita Euskal Herria ikusgarri egiten baita. Euskalduna da itsasontzia, Victoria, mundu-bira burutu duena; euskalduna baita ere kapitaina, Elkano; eta euskaldunak itzulitako beste hiru marinel ere, hirurak Juan izenekoak. Hantxe euskara, beraz, bidaiaren 1.082 egun eta gau bakoitzean.

\subsection{Del Cano inperiala}

Baina, nor zen Elkano? Atzean utzi dugu xalo-aroa. Badakigu historia ez dela neutrala. Ariketa politikoa da historia, botere-ariketa disimulatua, balio epistemiko batzuek behartutako zintzotasun akademiko minimoaren mugetan, ordaintzen duenaren ideologia laguntzera datorrena. Lurralde bakoitzean berea. Zinikoki begiratzen dugu mundu-bira nork kontatu —portugaldarrek, amerikarrek, espainolek edo filipinarrek — aldeak daudela; testuinguru kultural eta politiko bakoitza bere interpretazioa bultzatzen ari delako. Konparatu bestela Wikipedian batzuen eta besteen 'mundu-bira' sarrerak.

Gurean, Ebrotik behera sendo jarraitzen du Elkano inperiala marrazteko asmoak. Madrilen eta Sevillan horretan ari dira. Zuloagaren koadroan edo Getariako plazako eskulturan agertzen den pirata itxurako gortesau gaztelar hori aurkezten digute, Del Cano, Gaztelako koroaren zerbitzuko espainiarrak munduari bira eman ziola irudikatzeko. Gero eta agerikoago denez, ordea, Del Cano edo Elcano inperial hori nazionalismo espainiarraren produktua izan da, komenentziaz asmatutakoa, biografia fikzionatua. Hasi XIX. mendean, frankismoan indarra hartu eta, orain bertan, Europar Batasuneko diru funtsen laguntzaz, bosgarren mendeurrena marrazketarako baliatzen ari den elite espainiarrarena.

Era berean, 2019ko uztailean, Juan Sebastian Elcano armadako gerraontzia Getariara hurbildu dute (Bilboko Ingeniaritza Eskolaren laguntzaz) Elkano getariarra trapu inperial apainetan mozorrotzen jarraitu eta gorazarre nazionalista gure lurretaraino ekartzeko, Koroaren, Armadaren eta Ebanjelizazioaren zerbitzura. Espainiatik datozen marko eta ideologia nazionalista erreakzionarioena gure lurretan. Gure lepotik, gure herrian, nazionalismo espainol inperialista bere piezak mugitzen eta horretarako Elkano desitxuratzen jarraitzen. 


\subsection{Nola emango diogu buelta?}

Euskal Herrian ia inori ez zaio Elkano inperial hori gustatzen, jakina. Baina nola irauliko dugu? Panpina gehiago bihurritu genezake, Pizarro edo Hernan Cortes konkistatzaileen pare jarrita. Gurea ere emakume-bortxatzaile eta indigenen hiltzaile izan zela ziurtzat emanda. Batzuk horretan saiatzen ari dira. Baina horrek Elkano inperialaren asmakuntza indartzen du. Inperiozaleei bere merkantzia erosten die. Eta, ohartzen ari garenez, Elkano inperiala XIX. mendeko nazionalismo espainolaren eraikuntza berantiarra da.

Gure historia idazterakoan ez genuke Madrilgo historiagileen premisa faltsuetatik abiatu behar. Are gutxiago kontra egiteko bada, kontra egitean amuak gogorrago tenkatzen gaituelako.

\section{Espedizioaren lorratz germaniarra}

Gaztela-Portugal auzi artifiziala, esaterako, mundu-biraren domina nori dagokion ari garenean agertu ohi den auzia da. ${ }^{15} \mathrm{Ez}$ ote du praktikan funtzionatzen espedizioaren lorratz germaniarra ezkutatzeko? Karlos V.a germaniarra zen eta haiei zor zitzaien (Greengrass 2015 [2013]: 324). Ondorioz, 1519an oraindik bere gortean nederlanderaz aritzen ziren, edo frantsesez. Gainera, espedizioa finantzatzeko erregeak jarritako dirua ere Alemaniatik zetorren Fugger familiaren bitartez. Eta itzuleran espedizioak Moluketatik ekarritako iltze guztia Welser familiak erosi zuen; alemanak ziren haiek ere. Beraz, proiektuari oniritzia habsburgotar batek eman zion, eta alemanek finantzatu zuten. ${ }^{16}$

\footnotetext{
15 Espainiako Historiaren Errege Akademiak 2019ko martxoan txostena idatzi behar izan zuen auzia ebazteko: «Gertakizun historiko objektiboek frogatzen dute ludiari bira eman zion balentria haren espainiartasun ofiziala. Magallaes portugaldarra zela baliatuz balentriaren aitatasuna eskuratzeko Portugaleko agintaritzak propio zabaldutako hainbat zalantzari erantzuten dio jasotako eskariak» («Los hechos históricos objetivos que demuestran la españolidad oficial de la gesta marítima que culminó con la Primera Circunnavegación a la tierra. La petición recibida se basa en la necesidad social de atender a los muchos interrogantes que han planteado las autoridades portuguesas al intentar capitalizar la paternidad de la gesta por ser Magallanes natural de Portugal»). Txostenaren ondorioa zalantzagabekoa da, mundu-bira guztiz eta bakarrik espainola izan zen, «plena y exclusiva españolidad» alajaina: «Halako datuekin —erabat dokumentatuak daude-, erantzunezina da ekimena guztiz eta bakarrik espainarra izan zela» («Con tales datos, absolutamente documentados, es incontestable la plena y exclusiva españolidad de la empresa»). Historiagile espainiarrak itsutzen jarraitzen duen nazionalismoaren adibidea, XIX. mendera atzeratu gabe, iazko txostenean.

16 Espainiako Historiaren Errege Akademiak mundu-birari buruzko txostenean: «4. Bidaiaren kostuak honela ordaindu ziren: \% 75 Gaztelako Koroak eta beste \% 25a burgosko merkatari talde batek, Cristóbal de Harok batez ere, espezia merkatari ezagunak» («4 ${ }^{\circ}$. El coste de la expedición estuvo sufragada de la siguiente manera: un $75 \%$ por la Corona castellana y el otro $25 \%$ por un grupo de comerciantes burgaleses entre los que destaca Cristóbal de Haro, importante mercader en el comercio de las especias»). Diru alemanaren arrastorik ez.
} 
Magallaesek Portugaldik ekarri zuen mendebaldeko espezia-bidea irekitzeko proposamena. Portugalen arrastoa ere nabaria da, beraz, batez ere bidaian zehar, portugaldarrek aginte-posizioak izan zituztelako ibilbidearen zati nagusian. Portugaldarren askonahia eta modu militarra garrantzitsuak dira bidaian zehar gertatutakoak ulertzeko. Baina espedizioaren asmoak eta nondik norakoak ulertzeko garrantzitsuagoa da akaso, eta ez da ia aipatzen, Alemaniaren egitekoa, germaniarrak zirelako orobat bai proiektuaren diseinu erreala, bai hura gauzatzeko baldintzen bermea jarri zutenak.

Espedizioa abiatu zenean, 1519an, Gaztelak praktikan mailegu-emaile alemaniarrentzako berme ekonomiko moduan funtzionatzen zuen (Greengrass 2015 [2013]: 325, 328) eta, besteak beste, horregatik zeuden gaztelarrak sutan Karlos V.arekin (Greengrass 2015 [2013]: 310). Ulertzekoak dira gaztelarren susmoak, Tordesillasko Itunaren ondoren (1494) Gaztelak Amerika eta haien atzeko Moluka uharteen jabetza-eskubideak eskuratu zituelako. Horiek guztiak alemaniarrentzat?

Gaztelar-gaztelarra dena orduantxe Hernan Cortesek gidatutako Amerikako konkista da, hango sarraskia eta harrapaketa jarraitua. Baina, hain zuzen, horregatik Moluketarako bide-irekiera ezin da 'konkista basatiaren' zaku horretan sartu, besteak beste, proiektuaren nortasunean elite germaniarren izaera merkatari eta praktikoa nagusitzen zaiolako hasieratik, konkistatzaile gaztelarren izaera purtzil, gailentzaile eta kriminalari. ${ }^{17} \mathrm{Eta}$, bestetik, Molukak urrutiegi daudelako oraindik okupazio/mehatxu militar egonkor baterako. ${ }^{18}$

\subsection{Bazterrean utzia}

Mundu-birari buruz ezagutzen den lehenengo kontakizunetakoa Pedro Martir Angleriakoak idatzi zuen, urte haietantxe eta zuzeneko testigantze-

\footnotetext{
17 'Izaera' aipatzean ez naiz pertsona jakin bati buruz ari, ezta herrialde bateko herritar guztiei buruz ere, baizik eta herrialdeek orokorrean hartu zituzten jokatzeko moduei buruz ari naiz, herrialdeen arteko desberdintasunak nabariak zirelako. «Kolonizatzaile europarrek ozeanoaz bestaldeko koloniak administratzeko modua aldatu egiten zen batzuetatik besteetara, aurkitzaileen jatorriaren arabera eta ezarri nahi zuten nagusitasunaren arabera» (Greengrass 2015 [2013]: 187) ( «El modo en que los colonizadores europeos administraban sus colonias ultramar difería dependiendo del origen de los descubridores y del tipo de dominio que querían establecer»). Bereizketa horrekin ez nuke kolonizatzaile 'onik' iradoki nahi, kolonizatzaile europarrekiko gaitzespena orokorra zelako: «Rijkoff van Goens, Holandari lotutako Ekialdeko Indien Gobernadore Nagusia (1678-1681), bere europartasunaz ohartuta zegoen 1675ean: "Asiako nazio guztien artean ikaragarri gorrotatuak gara”» (Greengrass 2015 [2013]: 197) («Rijkoff van Goens, Gobernador General de las Indias Orientales Neerlandesas (1678-1681), era muy consciente de su europeidad cuando escribía en 1675: 'somos mortalmente odiados por todas las naciones de Asia»).

18 Asiako konkista militarra Felipe II.ak hasi zuen Filipinetan, 1565. urtetik aurrera, ManilaAcapulco erraz-bideaz baliatuta.
} 
tan oinarrituta (Décadas de Orbe Novo, 1511tik 1526ra argitaratuak). Gutun formako kontakizun eta interpretazio nahas-mahas horretan, mundu-birak Gaztelako gortean izandako harrera antzematen da. Eta irakurtzen dugu orain testu hura, Elkano zerbitzari leialaren bila, nola goresten duten aurkitzeko gogoz, eta hara non, 17 orriko kontakizun luzean, Elkanoren arrastorik ez dagoen. Ezta behin ere, haren izenik ez da aipatzen. Hain inperial izandako kapitainak ez du gortearen laztan txikienik merezi?

Angleriak ezjakintzat zituen Sevillara iritsitako 18 marinelak, guztiak xaloak bezain fidagarriak iruditzen zitzaizkion. Benetako heroia Hernan Cortes zen, Orbe Novoaz jabetzeko proiektu inperiala gogobetez konplitzen zebilena Amerika gaztelarrentzat konkistatuz. Ez marinel xalo hauek, sekulakoa egin zutenak —Orbeari bira eman- nahigabe bezala, ia kasualitatez, kontzientzia historikorik gabe. Gutxietsi egiten zuen Elkano.

Mundu-birari dagokionez, heroi bakarra kabitzen da Madrilgo gortean: Magallaes. Portugesen traidore espainiartu berria. Magallaes, koroaren eta elizaren zerbitzari fina. Koroaren lagun militar ebanjelizatzaile esanekoa. Martiria. Portugal abandonatu zuena Espainiaren gailentasunaz ohartu zelako. ${ }^{19}$

Elkanori buruz, ordea, hitz erdirik ez. Nola aldatzen den bertsio ofiziala. XVI. mendean bazterrean uztetik, orain armadako gerraontzi handienari bere izena jartzera. Zer gertatu da? Laburrean: gure historia idazten digun nazionalismo espainolaren interesak aldatu direla bitartean. Magallaes goratzea komeni zen auzia Gaztela-Portugal zen garaian, edo nobleziaren agintzeko naturaltasuna edo erregearen ukiezintasuna —erregeak hautatu zuen Magallaes—. Auzi eta larritasun politikoak aldatzean, ordea, xIx. mendean, Elkano berreskuratu zuten, periferiako herritar hezigaitzak ere espainol loriatsuak izan gaitezkeela gogorarazteko.

\section{2. «Xume eta esaneko»?}

Juan Cotarelo militarrak, esaterako, 1861ean Elkanoren biografia labur bat argitaratu zuen, lehenetarikoa (Biografía de Juan Sebastián de Elcano). Espainia iparraldeko kanpaina militarretan karlistak borrokatzen zituen bitartean Elkano «xume eta esaneko» ${ }^{20}$ zela diosku, izaera «sumisoa» zuela mun-

19 Magallaes santu egiteko mirari-egile ere jartzen dute, hilzorian zena sendatuta: «Eta kapitainak animoari eusteko eskatu zion, eta Kristoren federa etorri nahi bazuen, sendatuko zela. Indiarra pozik joan zen, gurutzea gurtu ondoren, bataiatu egin zen, eta hurrengo egunean osatu zela esan zuen eta ez zuela ondoezik batere sentitzen» (Fernandez de Oviedo 2011 [1535], XX. liburua, 1 kapitulua, 14 orria) («E hisole el capitán entender que estoviesse de buen ánimo, y que si se quisiesse convertir a la fee de Chripsto, luego sanaría. El indiano fue contento, é aviendo adorado la cruz, se baptisó, y el día siguiente dixo que era sano é que no sentía mal ninguno»).

20 «de condición sencilla y obediente» (Cotarelo 1861). 
duari bira ematea lortu zuenak. Eta frogatzat jartzen du itzuliari buruzko Valladolideko ikerketa zorrotz eta zakarrean Elkanok 13 galderak modurik apalenean erantzun zituela. Froga arraroa, halako ondorioa ateratzeko. Elkano obeditzailearen errelato berantiar hau sinetsiko diogu mariskalari?

Elkanok emandako erantzunei arreta jarrita (Bernal 2019a [1522]), urrutiago joan gabe, Elkano obedientea baino Elkano apala agertzen da, garbia, bete-betea, goitik beherakoa, tolesdura politikorik gabekoa. Bidaia katramilatuan zehar hartu behar izan zituzten erabaki zail guztiak esaldi laburretan azaltzen dituena, erretorika itsutzailerik gabe. Zentzu komuna hizketan. Eta iritzi irmokoa, bere aurreko kapitainek hartutako hainbat erabaki ere txikiesten dituena, inorekiko herra pertsonalik batere erakutsi gabe. Barkuetan izandako barne-gatazken kontakizun fidagarrienetakoa eskaintzen du Elkanok, eta bere testigantza irakurtzean pertsona fidagarria izatearen inpresio osoa ematen du. Obedientea zen Elkano? Fidagarria zela ziur.

\subsection{Del Cano inperialari bira}

'Historiagile' — kasu horretan militar — espainiarrei sinetsi aurretik hainbat galdera egin beharko genituzke: 'Iparraldeko' karlisten jazarleari zergatik interesatzen zaio hainbeste Elkanoren biografia? Zergatik justu 1861ean? Zergatik justu «Xume eta esaneko» aurkeztu euskaldun eredugarria? Juan Cotarelo eta antzeko enparauen interes militarren pozoitik ez genuke edan behar. $^{21}$

Elkano euskaldun begiz begiratzen ikastea proposatzen dut, 'esaneko Elkano' mespretxatu aurretik, gure juzkua kutsatzen duten aurreiritziak gainditzera hel gaitezen. Elkanoren aurkako energia kritikotik asko berbideratu beharko genukeela pentsatzen dut, Del Canotik atera eta 'historiagileek' eraiki diguten gure herriaren errelatoa deseraikitzera zuzentzeko.

Kritikoenak garelako ustean, askotan akritikoenak gara. Kontakizun pozoitsua modu akritikoan jasotzea ez delako barkatzen gero hari kontra eginda. Akritiko jasotakoari kontra egiteak ez gaitu kritiko bihurtzen.

\section{Marinel desobedientea}

XVI. mendeko Gaztela inperialarentzat Elkano pertsonaia deserosoa zen. Batetik, abizen plebeioa zuelako, ez noblea, kapitainak. Gorteak ez du plebea

21 Garaiak ez dira askorik aldatu. XIX. mendean bezala gaur, militar espainiarrek kontatzen dute Elkanoren historia. Mundu-birari buruzko «Sin límite» seriea (RTVE eta Amazon Prime), esaterako, Espainiako Defentsa Ministerioak bultzatzen du. 
goresten. Plebeioa kapitaintzara heltzea bere horretan da urratzailea. Mundubirak ireki zion plebeioari gorteko sarrera, ez abizenak.

Baina, bestetik, desobedientea izan zelako zen deserosoa. Koroaren zerbitzuko historiagile horiek kontatzen ez dutenez, komeni zaigu jakitea: ez behin, askotan desobeditu zuen Koroa Elkanok. Esaterako, nori saldu zion barkua? Atzerriko potentziei, eta legez kanpo. ${ }^{22}$ Nabigazio sekretuak saldu zizkien atzerritarrei. Nonbait, ez zitzaion hain leiala ere Inperioari. Eta bidaiaren lehen zatian, zergatik zigortu zuen Magallaesek eta kargugabetu? Aurre egin ziolako, ibilbidearen nondik norakoak erakuts zitzan. Ez zion halako begiramen handirik Koroaren aginte eta boterea ordezkatzen zuen Magallaesi, obeditzen jarraitzeko proiektua partekatzeko eskatu zionean. ${ }^{23} \mathrm{Ma}-$ gallaesen aurkako matxinadaren egun haietantxe izan zenez, Elkano ere gogorki zigortua izan zen. ${ }^{24}$ Borneoko erregeak zergatik ez zuen Elkano hil, eskura izan zuenean, Carvalho kapitainaren erasoak mendekatzeko? Beharbada, Elkano haiekin batu zelako Carvalho burugabea paretik kentzeko. Galdera da: hango buruzagiekin batera antolatu zuen Elkanok bere kapitain Carvalhoren erorialdia? Ziurtasunez esateko ez dakigu, eta zaila izango da inoiz jakiten, bakoitzak bere erara kontatzen duelako han gertatutakoa. Baina posible da halako zerbait gertatu izana, uharteko buruzagiak Elkano ontziratzen utzi ondoren txopakoek Carvalho kendu eta Elkano jarri zutelako kapitain. Zein 'konkistatzaile' xelebrea gurea, kapitain europarrak erauzteko 'indigenekin' aliantza politikoak adosten dituena.

Eta, garrantzitsuena, zergatik bukatu zuen mundu-bira? Koroaren aginduei jaramonik egin ez zielako. Espedizioak agindu zorrotzak zituen, esplizituak, joandako bidetik itzultzeko. Batetik, espezien bide berria irekitzeko eta, bestetik, Portugalen domeinuko uretatik ez igarotzeko. Baina Elkanok mendebalderantz jarraitu zuen erregearen aginduari jaramonik egin gabe, bizirik itzultzeko aukera hori zutela iritzita. Eta erabaki horregatik, hain zuzen, eman zion munduari bira. ${ }^{25}$

22 Itzulia eman ondoren barkatu zion Erregeak lege-zor hori Elkanori, 1523ko otsailaren 13an. https://dokuklik.euskadi.eus/badator/visor/629675

23 Valladolideko gortean horri buruz galdetuta, Elkanok ez zuen desobeditu izana aldarrikatu. Alderantziz, Magallaes ari zela errege-agindua desobeditzen argudiatu zuen, itsas ibilbidea ez partekatzeagatik. Historiografia espainiarrari Magallaes goratzea komeni izan zaion garaietan, Magallaesen 'desobedientziak' haren aginte-senari lotu izan zaizkio.

24 Mafrak honela kontatzen du: «Eta Juan Sebastián del Cano jarri zuten bestearen kapitain, zeinak itsasartetik Magallaes hil arte tratu oker asko jasan behar izan zituen, eta apal-apal jasan zituen, harik eta galdutako kargura itzuli zen arte» (Ginés de Mafra 1522, XV. kapitulua —ikus Elcano et al. (2018)—) («E hicieron capitán de la otra a Juan Sebastián del Cano, que desde el estrecho hasta que murió Magallanes, había sufrido muchos disfavores, mas él como discreto sufrió hasta que tornó a su cargo que había perdido»). Kargugabetzea eta bestelako ‘disfaboreak' neurriz jasan zituen Elkanok. Hitz ederrak dira, hark ere Elkanori zion miresmenaren lekuko.

25 Elkanok, jakina, ez du bere erabakia 'desobedientzia' ariketa gisa azaltzen. Batetik, Pigafettaren (2019 [1522]) kontakizunean argi irakurtzen da erabakia kolektiboa izan zela, marinelak 
Mundua biribila dela egiaztatu zen euskaldun batek Gaztelako Koroaren agindu zehatzak kontzienteki desobeditzea erabaki zuelako. Munduaren forma eta tamainari dagokionez, Aristoteles eta Biblia oker zeuden, beraz. Eta nork frogatuko eta euskaldun batek, nola eta erregea desobeditu zuelako.

\subsection{Gure errelatoaren beharra}

Elkanok gustura kontatzen zuen mundu-bira bere ideia izan zela. Eta kontatzeko egin zuen, gainera (Mazón 2020a: 157). ${ }^{26}$ Moluketatik atzeraka itzuli beharrean, Espinosa kapitaina bezala, aurrera egiteko erabakia hartu eta marinelei eskatu zienean bere barkua aukeratzeko, arrazoi horixe eman zien: kontatzeko modukoa egitera zihoazela. ${ }^{27}$

Orain ulertzen da XVI. mendeko gortesau, noble eta eliteek Elkano maite-maitea ez izatea. Edo zergatik ez zizkioten ordaindu, ez inoiz ordainduko, ondo irabazitako urteko 500 dukatak. Edo zergatik ezkutatu zuten bere izena 300 urtez bidaiaren kronika nagusietatik. ${ }^{28}$ Edo zergatik jokatu zuten hain

\footnotetext{
ados omen zeuden. Gehienak behintzat, Ayamontek bere kontakizunean esaten baitu Elkanok bultzatutako erabakia izan zela: «Maisuak eta pilotuak, biak greziarrak [Miguel de Rodas eta Francisco Albo], Malakatik itzuli nahi zuten, eta kapitainak, bizkaitarra bera, ez zuen nahi» («El maestre y el piloto, que eran griegos [Miguel de Rodas eta Francisco Albo], quisieron venir por Malaca, y el capitán, que era vizcaíno, no quiso»). Bigarren, Elkano hegoaldera abiatzen da eta, beraz, nolabait esan daiteke, oso nolabait bada ere, erregeak Magallaesi emandako mandatua bete duela: «Joan behar duzuela eta zoaztela aurkikuntzak egitera itsas ozeanoaren gure zatia zedarritzen duten mugetatik atera gabe» (Bernal 2019 [1518]: 2) («hayáis de ir y vayáis a descubrir a la parte del mar océano dentro de nuestros límites y demarcación»), Portugalko ontziekin topo ez egitearren gogor saiatzen baita portugaldarrak inoiz ibili gabeko hego-hegoko itsasotik itzultzen. Eta, azkenik, erregeari gutunez erabakia azaltzen dionean, Sanlukarrera iritsi berri-berritan, zerbitzari onaren argudioa erabiltzen du: «zu zerbitzatzeagatik maiestate edo hiltzea edo ohore handiz aurkikuntza haren berri izan zenezala erabaki genuen, Jainkoak bromaz jositako ontzi bakarrarekin abiatu ginenean» (Elkano, 1522ko irailaren 6ko gutuna) («determinamos de morir o con grand honra a serviçio de tu alta magestad, por haserla sabidora del dicho descobrimiento, con una sola nao partyr estando tal de bromas como Dios quería.»)

${ }^{26}$ Mazónek (2020b) ere ez dio bestelako azalpenik topatzen norabide hori hartzeari: https:// www.youtube.com/watch? $\mathrm{v}=5 \mathrm{JeHicQ}-5 \mathrm{~T} 4 \& \mathrm{t}=278 \mathrm{~s}$ (55' minututik aurrera.)

27 Erregeari idatzitako gutunean ere munduari bira eman izanaren kontzientzia eta harrotasun hori nabari dira: «Jakingo duzu maiestate estimu handiena izan behar diogula munduaren biribiltasuna aurkitu eta inguratu izanari, mendebaldera joan eta ekialdetik itzuli baikara.» (Elkano, 1522ko irailaren 6ko gutuna) («Más sabera tu Alta Magestad lo que en más avemos de estimar y tener es que hemos descubierto e redondeado toda la redondeza del $\mathrm{m}[\mathrm{u}]$ ndo, yendo por el oçidente e veniendo por el oriente.»)

${ }_{28}$ Salbuespena Rodrigo Aganduru Moriz da, Filipinetan misiolari zebilen fraide agustindarra. Aganduruk Elkanori gorazarre egiten dio, nabarmen, Filipinetako historia egiten duen liburuan, 1610eko hamarkadan. Parekorik ez duen Elkanoren aitorpen hori ulertzeko bi arrazoi egon litezke. Bat: Aganduruk behin eta berriz errepikatzen du Elkano Filipinetara portugaldarren aurretik iritsi izanak ematen diela gaztelarrei zilegitasuna. Bi: Aganduru oriotarra da.
} 
zakar gorteko 'ikertzaileek' Elkanorekin. Edo bere kontakizun idatzia galtzea, zabalkunderik inoiz eman gabe.

Azken batez, Elkano plebeioa txopakoek izendatu zuten kapitain, ez Koroa espainiarrak. Eta horregatik iritsi zen Victoria Sevillara, marinel euskaldunaz fidatu zirelako. Erregearen agindua ahaztu zuelako. Munduari bira osoa emateko kolpe bakarrez batera irauli zituen biak, garaiko ordena politikoa zein ordena metafisikoa. Erregea eta Aristoteles biak batera desautorizatu zituen getariarrak, desobeditu zuenean.

Horiek guztiak jakinda, Elkano inperialaren ordez gure errelatoa kontatzea dagokigu, historikoki zorrotzagoa dena espainiar inperialismoaren zerbitzura asmatu dutena baino.

\subsection{Del Canoren asmakuntza}

Egiazki ez dakigu Elkano nor izan zen, batez ere bere oroimena nahita desitxuratu delako eta bidaiaren bere errelato idatzia desagertu egin delako. Beraz, gutxi jakin dezakegu Elkanori buruz, baina dakigun apurragatik, gutxien-gutxienik ezpal inperialik ez zuela ondoriozta dezakegu. Esaterako, jatorri noblekoa zela, hori ere Navarreteren asmakizuna da. Elkanotarrak plebeioak ziren, ez dute noble gisa sinatzen, eta Juan Sebastian noblea izan balitz ez ziokeen erregeari armak eramateko baimenik eskatu behar izango. Edo beste hau, euskaraz egiten zuela zalantzan jartzea, propio asmatutakoa, Elkanok ederki egiten baitzuen euskaraz.

Baldar egitekotan, gaztelaniaz egingo zuen hala moduz. Elkanok Sanlukarretik bidalitako gutuna Valladolideko gortera iritsi zenean, pentsatzekoa da idazkari ikasiek irakurriko zutela. Eta hain gaztelania traketsean idazten duenak, «la paz e amistad de todos los reyes e señores de todas yslas sobredichas, queriéndote obedeçer como a rey e a señor, firmadas de sus propias manos, llevo a tu Alta Magestad», ezin jaso lehen iritzi onik halako buruharro artean. Zenbat trufa ez ote zituen jasango horregatik gorteko korridoreetan, Erregeari gutunean túka egin ziolako adibidez. ${ }^{29}$

Itsasgizona bikain moldatzen zen itsasoan. Jauregiko kodeetan, ordea, traketsa zen, arrotza, kuriositate bat. Eta, hala ere, behera begiratzen dutenek ere onartu behar dute Elkano, arreta jarri behar diote, isil-isilik entzun. Sinpleki, munduari bira osoa eman diolako. Noble handiuste haiek inoiz iri-

\footnotetext{
29 Erregeari túka egiten dion gutun bakar horren kopia originalik ez daukagu. Iritsi zaiguna kopia bat denez, ezin da ziurtasunez baieztatu Elkanok gaztelania traketsa zuenik, gaizki kopiatua izan litekeelako ('su' ordez 'tu' jarrita, agian). Pertsonaiak darabil gaztelania baldarra ahoan, baina pertsonak zer zerabilen ez dakigu. Egunen batean bidaiaren bere kontakizuna topatzen bada, gaztelaniaz nola moldatzen zen ere orduan argituko da.
} 
tsiko ez ziren herrialde urrunenak eta jendarterik bitxienak bertatik bertara ikusi zituelako, jakin-mina sortzen zuen. Eta hitz egiten uzten zioten, opari bat emango baliote bezala. Kronika ofizialetan jasotzen duen bazterreko trataera ikusita, ordea, ederki antzematen da benetan ez zutela askorik errespetatzen, eta ez zutela inoiz haietakotzat hartu.

Hiru molukar Sevillara ekarri zituela ere kontatzen da, frogatu nahian bezala bera ere konkistatzaile-esklabozale aritu zela, gaztelar edo portugaldarrak bezala. Aitzitik, hiru molukar haiek, gainerako txopakoak bezala, soldatapean izan zituen Elkanok. ${ }^{30}$ Eta Sevillara iristean aske lurreratu ziren, ez ziren elizara sartu, nahiago izan zutelako merkatua ezagutu. Gainera, hirutik bik Elkanoren hurrengo espedizioan parte hartu zuten eskifaia kide gisa. Hirugarrenari ez zioten utzi, Oviedok kontatzen duenez, ${ }^{31}$ espezien merkatu-balioaz gehiegi ikertu zuelako eta gaztelarrek ez zutelako truke-balioaren informazio hori Moluketara iristerik nahi.

Cabo Verdeko lehorreratzea kontatzerakoan ere, behin eta berriz aipatzen da 'esklabo' edo 'beltz' bila jaitsi zirela. ${ }^{32}$ Baina etsipena aipatzea falta da. Bidaiaren azken-azken zatia zen eta hilabeteak zeramatzaten lurrik zapaldu gabe. Astean bi-hiru hildako izaten ari ziren, ontzi-zuloetatik sartzen zen ura

30 Molukar batek 12.000 marabedi jaso zituen Sevillara iristean, berak zekarren iltzearen truke. Pigafettak (2019 [1522]) ere aipatzen du (1521eko abenduaren 21eko sarreran) molukarrak pilotu-laguntza egiteko kontratatzen zituztenean «aurretik ordaintzen» zitzaiela.

31 «Enperadorea, gure jauna, ikusi eta ezagutu nahi zutenez kapitain honek [Elkanok] berekin ekarri zituen lurralde haietako hainbat indio, jakin nahi zutelako gure aberri eta erreinuen berri eta gure Espainiako jendeen berri; haien artean etorri zen bat aurreratua, jakintsua eta halako zuhurtziaren jabea ezen, Gaztelara iritsi bezain azkar, egin zuen lehenengo gauza dukata batek zenbat erreal balio zuen galdetzea izan zen, eta erreal bakoitzagatik zenbat marabedi, eta marabedi bakoitzagatik zenbat piperbeltz ematen zuten galdetu zuen han eta hemen, Sevillatik Zesarren gorteraino. Eta horretan ari zela, dendetara sartzen zen eta espeziak saltzen dituzten botiketara, eta marabedi bat piperbeltz erosten zuen, eta guztietan informazioa eskuratzen zuen espeziek gure lurraldean zenbat balio duten; hain zen abila horretan, bere ohartarazpenaren beldur, agindu baitzen ez zedila inoiz bere jaioterrira itzuli, Jofre de Loaysaren espedizioan beste indioak itzuli ziren moduan.» (Fernandez de Oviedo, 2011 [1535], XX. liburua, IV. kapitulua, 32. orria) («Trajo este capitán consigo algunos indios de aquellas partes que deseaban ver y conocer al Emperador, nuestro señor, e informarse de nuestra patria y reinos y gente de nuestra España; y entre aquellos vino uno principal, sabio y de tanta astucia que, llegado en Castilla, lo primero que hizo fue inquerir cuántos reales valía un ducado, y un real cuántos maravedíes, y por un maravedí cuanta pimienta se daba en diversas partes, desde Sevilla hasta la corte de César. Y en ella estando, luego iba a las tiendas y boticas de los especieros, y compraba aquel maravedí de pimienta, y en todos se informaba del valor que las especias tenían entre nosotros; y estaba tan diestro en ello que, temiendo su aviso, dio causa a que nunca volviese a su tierra, como tornaron los otros indios con la armada de [...] Jofre de Loaysa.»)

$32 \mathrm{Ez}$ da ziurra esklaboak erostera jaitsi zirenik Cabo Verdeko portura. Asko dira Cabo Verdeko lehorreratzearen testigantza ematen duten marinelak (Albo, Pigafetta, Elkano, Bustamante eta Cabo Verden atxilo hartu zituztenak). Soilik Bustamantek aipatzen du esklabo bila jaitsi izana, gainerako guztiek jaki bila jaitsi zirela esaten dute soilik. Zergatik ez du beste inork aipatzen esklabo-tratuaren asmoa? 
ateratzeko indarrik ez zeukaten eta azkenean lurreratzea erabaki zuten jatekorik ere ez zutelako. Laguntza-behar larria zuten. Gainera, gauzak okertzeko, ez zuten zerekin trukatu janari eta lan-indar hori. Nola ordaindu portugaldarrei? Ontzian iltzea bakarrik izanda, hura erakutsi bezain pronto euren burua salatuko zuten, iltzea Moluketatik bakarrik zetorrelako. Eta halaxe gertatuko zen, ziurrenik: behin jakiak eskuratuta, hurrengo txalupa lan-indar bila abiatu zenean, nondik zetozen agerian jarri eta haien aurka aterako ziren portugaldarrak. Gaizki aterako zitzaien lehorreratzea, lan-indar bila jaitsi eta 13 lagun gutxiagorekin jarraitu behar izango zutelako Sevillara bitarteko azken zatia. Jakiak eskuratu zituzten gutxienez. Bazekiten lan-indarra iltzearekin trukatzea erokeria zela, eta hala ere egin-behar horrek erakusten du etsipenaren neurria.

Badakigu, baita ere, kapitain izan zen bitartean Elkanok ez zuela inor hiltzeko agindurik eman. Ez 'indigena', ez txopako. Eta erabaki inportanteenak tripulazioarekin kontsultatuta hartu zituela, elkarrekin bozkatuz. Itsasontzi-kapitain «demokrata». Platonek Politeia liburuan (488a-489d) dio barkua ezin dela demokratikoki gobernatu. Antzinatean ez ezik, gaur egun arte ere salbuespen gutxi aurkitzen zaizkio argudio antidemokratiko horri. Salbuespena nork jarriko eta, berriz ere: Elkanok, Getariako semeak.

Platon, Aristoteles, Biblia eta Erregea. Bidaia hura bururaino eramateko mendebalde kulturaleko zutabe politiko, filosofiko eta metafisiko sendoenak jarri behar izan zituen balantzaka Elkanok.

\subsection{Amuak}

Marinel aparta, ausarta, fidagarria eta behar zenean desobeditzailea. Injustua litzateke Elkanok merezitako aintzarik ez jasotzea. Are gehiago: ez konkistatzaile, ez ebanjelizatzaile, ez Koroaren zerbitzari leial izan zen. Zertarako jarraitu halako etiketekin Elkanoren memoria zigortzen, ziurrenik ez badu bakarra ere merezi? Bai mundu aldrebesa, orain guk Elkanoren kontra egiteko ezaugarri horiek erabiltzea, nahikoa zigor jaso zuenean Elkanok bere garaian, hain justu, halako ezer ez izateagatik.

\section{Elkano, bere idatzietan}

Bere eskuz idatziak, Karlos erregeari zuzendutako pare bat «gutun» eta testamentua iritsi zaizkigu bakarrik ${ }^{33}$, Elkanoren pentsaera baino interesak erakusten dituztenak. Lehen gutuna, izatez 'oharra' edo 'abisua', Sanlukar de

\footnotetext{
33 Dokumentu horietara erraz iristeko web-orri egokiena Ruta Elcano da: https://www. rutaelcano.com/bibliografia-despues
} 
Barramedatik idazten dio, iritsi direla esateko, 1522ko irailean. Eta azaroan bertan idatziko dio bigarren gutuna, hobariak eskatzeko. Horietan Elkano praktikoa agertzen da, azken xehetasunera arte dena kontrolpean izatea gustatzen zaiona. Eta famarekin datorkion goranahia: itzuliaren ondoren gora egin nahi du sozialki eta ekonomikoki.

Erregearekin duen tratuan nabaria da, baita ere, diru-kontuetan gardentasunez jokatzen duela, Moluketatik dakarren zama hitzartutako moduan entregatzen duelako, azken gramora arte. Gizatasuna ere nabari zaio, Karlos erregeari egiten dion lehen eskaria, Sanlukarrera iritsi eta berehala, 1522ko irailaren hasieran, Portugalek Cabo Verden preso hartutako 13 lagunak libratzeko ahalegina egitea baita. Apala, gardena eta gizatiarra ageri da lehen gutunean. ${ }^{34}$

Laurgainen agertu berri den gutunean ere apaltasuna nabari da. 1522ko azaroaren 5ean idatzi zuen, mundu-bira eman, Valladolideko gortera iritsi eta 40 egunetara. Eta hobariak eskatzeko idazten dio, Kapitain Nagusi izendatzeko, adibidez, edo Magallaesi zegozkionak jasotzeko: Moluketako merkataritza-eskubideak edo Santiago Ordenako abitua. Errege-idazkariak, Francisco de los Cobosek, horiek denak ukatu zizkion. Magallaesi eskaini zizkioten hobari horiexek berauek ukatu zizkioten mundu-bira burutu zuen Elkanori. Gortean ez zuten askorik errespetatzen. ${ }^{35}$

Testamentua irakurrita ohartzen gara, inoiz ezkondu ez arren, bi bikote izan zituela gutxienik, biak euskaldunak edo euskal jatorrikoak. Mari Hernandez de Hernialderekin semea izan zuen, Domingo, eta Maria de Vidaurretarekin alaba, lehena mundu-biraren aurretik Getarian eta bigarrena mundu-bira ostean Valladoliden egonkortutakoan. Laurak eskuzabaltasunez tratatzen ditu ondasun-banaketan, eta nolabaiteko parekotasunez, lehen emakumeari 100 dukata eta bigarrenari 40 ematen badizkie ere. Eskatzen du, halaber, alabak lau urte betetzean Valladolidetik Getariara eramateko, ezkondu artean; erakutsiz alaba hazteko bere jaioterri Getaria kuttunagoa duela Valladolideko gortea baino. Erabaki hori ulertzeko, zentzuzkoa da pentsatzea Elkanoren azken nahia alaba elkanotarren leinura hurbiltzea izan zitekeela, besteak beste.

\footnotetext{
34 «Testu honen egilea itsastar zehatza da, soila eta zuzena. Eta oso azkarra.» (Aguinagalde 2019b: 295) («Quien escribe este texto es un marino preciso, escueto y directo. Y muy listo.»)

35 Aurrerago lortu zituen hainbat fabore: «Elkanok hainbat fabore jaso zituen, baina soilik hurrengo urteko urtarriletik aurrera: urteko 500 dukateko errenta (urtarrilak 23), atzerritarrei ontzia saldu izanaren aspaldiko delituaren barkamena (otsailak 13), eta arma gehiago eramateko pribilegioa (maiatzak 23). Bidaldiko hainbat kidek ere jaso zituzten.» (Aguinagalde 2019b: 298) («Elcano recibe diferentes mercedes solo a partir de enero del año siguiente: renta de 500 ducados anuales (23 de enero), perdón de un delito antiguo de venta de un barco a extranjeros (13 de febrero), y privilegio de aumento de armerías (23 de mayo). Como las reciben, asimismo, algunos de sus compañeros.»)
} 
Ondasunei garrantzia ematen diela ere nabari da. Argitzen du, esaterako, zorrik ez duela inorekin. Eta harrigarriena da nola, ozeano barearen erdian eta larriki gaixo, jabetza guztiak zerrendatzeko gai den, banan-banan, zehaztasun eta xehetasun osoz. Lapiko kopurua, esaterako, edo burko-estalkiak, eta halakoak, zerrenda amaigabean, jabetza bakoitza nori utzi agintzeko.

Hilburuko horri esker jakin dugu Elkanok bi liburu zituela. Irakurtzen bazekiela, beraz. Gainera, liburu bat gutxienez latinez idatzitakoa zenez, Almanaka izeneko urtekari astronomikoa, latinez ere irakurtzen zuelako ondorioa atera dezakegu. Beste liburuari buruz, berriz, gutxi dio, hura ere astronomiari buruzkoa zela bakarrik. Ondorioa da, izarrei begira nabigatzen zen garaian, Elkano astronomiaz interesatu zela, eta zeruak aztertzeko bi liburu zituela. Izarren posiziotik norbere posizioa eratortzeko gai izatea hil ala biziko kontua zen garai hartan, batez ere ozeanoarteko nabigazioetan, Elkanok astronomian interesa agertzen du, orduko protozientziaren laguntza eskuratu nahian, nabigazioa ere ahalik eta modu zientifikoenean egiteko.

Bitxia da bi liburuak Andres de San Martin pilotu-kosmografoari utzi zizkiola, mundu-biran desagertutako lagunari. Horrek iradokitzen du bigarren espedizioan Elkanok oraindik ere gordetzen zuela lehen espedizioan galdutako laguna bizirik topatzeko itxaropena.

Latinez irakurtzen zuen, astronomia interesatzen zitzaion, ez zituen lagunak erraz ahazten eta baikorra zen, itxuraz.

\subsection{Nazio-leialtasuna}

Euskaldunak dira, bera bezala, Elkanoren testamentu-lekukotza sinatzen duten guztiak. Zazpi lagunak. Ez dira euskaldun gutxi Ozeano Barearen erdian ausaz topatzeko.

Euskal hiztunen arteko nazio-leialtasunak bat-batean ageri dira hor. Nazioak asmakuntza modernoak direla uste duenarentzat ere, defendatzaile porrokatuenarentzat ere, zerbait esan nahiko du keinu horrek, ezta? Espedizioa multikulturala eta nazioanitza izan arren, kosmopolita erabat, hizkuntzak batzen dituela barkuko euskaldunak, gutxienez hori. Herrikideak batu egiten dira elkar laguntzeko, eta bidaiako mila arriskuen aurrean babesa eman eta hartzeko. Euskarak, gainera, babesleku naturala ematen zien garai hartako euskaldunei. Jakina da, esaterako, beste inork ulertzen ez zuenez sekretuak komunikatzeko euskarara jotzen zela bai gortean, bai gutunak idazterakoan. Barkuan ere horrelaxe jokatzea da normalena.

Eta nazioak batez ere komunikazio-espazioak direla uste bada, antiesentzialistak edo garelako, atxikimendu afektiboen kolektibo kultural eta politi- 
koak (Azurmendi 2015), hortxe agertzen da nazio bat, euskalduna, euskaraz hitz egiten dutenena, magia arrarorik gabe, XVI. mendean.

Herrien arteko mesfidantzak edo tirabirak ere ohikoak ziren espedizioan. Esaterako, Elkanok Valladolideko galdeketan emandako erantzunak irakurtzen badira, nabaria da bidaiaren kronika ia guztietan aipatzen den gaztelarren eta portugesen arteko bekaizkeria eta ezinikusia. Agian propio aipatzen ditu, belarri gaztelarrak goxatzeko. Izan ere, jakin badakigu bidaian zehar 'gaztelar' edo 'portugaldar' tribuak aski nahasiak zirela, eta marinelak multzo horietan sailkatzea gehiegi sinplifikatzea dela. Nazioak nazionalismoak asmatzen dituela diotenak harrituko dituen eran, hala ere, estatu-nazioak eta ideologia nazionalistak sortu aurretik, ehunka urte lehenago, herrikideak auzokoekin muturtuta ageri dira sarri espedizio beraren baitan. Edo gutxienez haren kontakizunean.

Halako bidaiak hain muturrekoak direnez, normala da konfiantza ere muturrekoa behar izatea, gertukoenen artean, eta naziokideka biltzea horretarako, hizkuntza bera hitz egitea izanik leialtasun espazio naturalena.

\subsection{Elkano, Maximiliano Transilvanoren kronikan}

Gatozen Elkanoren ustezko kontakizun idatzira, Elkanoren pentsamendua ezagutzeko gako nagusiak horrek emango baitizkigu.

Azkenaldian, Borja Aguinagalde Euskadiko Artxibategi Historikoko zuzendaria ari da Elkano ezagutzera ematen (Aguinagalde 2016, 2017, 2019a eta 2019b) eta, batez ere, Elkanoren bi «gutunak» aztertu ditu. Aguinagaldek ere entzuna du Elkanoren idatziaren inguruko afera, eta arrazoi sendoak ematen ditu kontakizun idatziaren alde: «Elkanok berak aitortzen du testu bat idatzi izana [...] zeinak bidaiaren azken zatia bakarrik jasoko lukeen» ${ }^{36}$ (Aguinalde 2019b: 300) edo «Litekeena da Elkano Sevillan Juan de Sámanorekin topatu izana [...] eta une horretan emango zion aipatzen duen kontakizun idatzia» ${ }^{37}$ (Aguinalde 2019a: 162-3) edo "Gonzalo Fernández de Oviedo kronikariak irmotasun osoz baieztatzen du 1557an testu horren existentzia» ${ }^{38}$ (Aguinagalde 2019a: 174). Baina, hala ere, Aguinagalderen jarrera pertsonala anbiguoa da, Elkanoren kontakizun idatziaren existentzia baieztatzen duen arren, aipu hauetan bezala, ondoren 'nolabait' ukatu egiten bai-

\footnotetext{
36 «El mismo Elcano dice haber escrito un texto (...) que solo cubriría el último año del viaje.» (Aguinalde 2019b: 300)

37 «Es probable que Elcano se encontrara con Sámano en Sevilla (...) ocasión en la que le entregaría la relación [kontakizun idatzia] que cita.» (Aguinalde 2019a: 162-3)

38 «El cronista Gonzalo Fernández de Oviedo confirma en 1557 con rotundida la existencia de este texto.» (Aguinagalde 2019a: 174)
} 
tu. ${ }^{39}$ Nolanahi ere, eta hemen ez nago ados, ontzat ematen du Transilvanoren kontakizuna Transilvanorena dela, hark marinelei entzun zienaren gainean idatzi omen zuelako, «Pentsatzekoa da bi egileek [Transilvanok eta Angleriak] entzundakoari buruz idatzi dutela» ${ }^{40}$ (Aguinagalde 2019b: 300). Beraz, Transilvano ez da ari Elkanoren testu idatzia jarraitzen, kopiatzen edo itzultzen, entzundakoen gainean bere kontakizuna antolatzen baizik. Bati baino gehiagori entzun dietenez, ezin erabaki ea zein zati den Elkanok esana. Gainera, Transilvanoren kontakizuna ez omen da erabat fidagarria, Gattinara bere patroiaren interesetara makurtzen baitu: «Transilvanoren helburua politikoa da, zalantzarik gabe. Premiazkoa da balentria ezagutzera ematea, baina mezua goxatuaz bere ugazaba Gattinara kantzilerraren gustu eta interesen

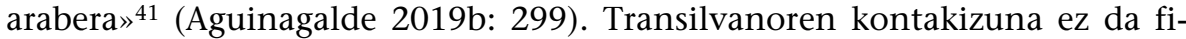
dagarria, entzundakoak jasotzen dituelako, hainbat ahots, eta politikoki kutsatuta dago. Hortaz, Aguinaldek arreta desbideratzea lortzen du, Elkanoren pentsamendua ezagutu nahi dugunok Transilvanoren kontakizunetik urruntzen gaituelako.

Bestelakoa da Enrique Santamaria idazlearen iritzia. Santamaria da, nagusiki, Elkano historiagintza ofizialaren atzaparretatik askatzen ari dena. Eta lohia kentzeko ahalegin horretan, besteak beste agerian jarri ditu bi gertakari garrantzitsu. Batetik, mundu-birako protagonisten kontakizun ia guztiak desagertu egin direla modurik misteriotsuenean. Esaterako, Elkanok idatzitakoa. Eta, bestetik, Maximiliano Transilvanoren kontakizunaren bigarren zatia, Magallaesen heriotzaren ondoren datorrena, Elkanori esleitu diezaiokegula ziurrenik.

Arrazoi sendoak daude Elkanok mundu-biraren kontakizuna idatzi zuela pentsatzeko, gutxienik kapitain izendatu ondorengo zatia. Eta bitxia da Eustaquio Fernández de Navarrete izatea hori aitortzen lehena. Bere Historia de Juan Sebastián del Cano (1872) liburuko 26. eranskina auzi horri eskaini zion,

39 Berriki esan du (2018ko otsailaren 6an) Elkanori ez zitzaiola kontakizuna inporta «ekintza bakarrik inporta zitzaiolako» eta abar: https://www.youtube.com/watch?v=TPV3ZiNwDxA (1:18' minututik aurrera). Euskaldunon (aurkako) estereotipo jakinarekin bat dator ikuspegi hori: euskaldunok ez dugu idazten, arlote horiek, ekintza-gizon ezjakinak garelako, pentsamendu abstraktu, arrazoibide korapilatsu eta analisi kritikorako ezgaiak. Aguinagalde ez da estereotipo horrekin bat etorriko, zalantzarik ez horretan, baina hori erabili du Elkano idazle ez izana justifikatzeko: getariarrak munduari bira eman nahi ziola, gero hori nork edo nola kontatuko axolarik gabe. Kontrara, badirudi Elkanori kontakizuna inporta zitzaiola eta, aurretik ez bazuen idatzi, Magallaesi zion beldurragatik izan zela. Hori esan zuen behintzat Valladoliden, Magallaesi zegokiola kontakizunaren ardura. Hor ere ikusten da, baita ere, munduaren bi ikuspegi kontrajarri zirela ontzian, Magallaesena eta Elkanorena. Bestela, zergatik izan beldurra Magallaesi?

40 «Es de suponer que ambos autores [Transilvano eta Anglería] escriben sobre lo que escuchan.» (Aguinagalde 2019b: 300)

41 «El objetivo de Transilvano es, sin duda, político. Es urgente dar a conocer la hazaña, pero modulando el mensaje al gusto y según los intereses de su patrono, el canciller Gattinara.» (Aguinagalde 2019b: 299) 
«Los papeles de Elcano», eta ondorioa argia da: Elkanok bere kontakizuna idatzi zuen. Hiru iturri aipatzen ditu hori frogatzeko. Lehena Elkanok berak Valladolideko lekukotzan egindako baieztapena, 1522ko urriaren 18an azken galderari erantzunez. Lekukotza horretan bere idatziaren bi kopia daudela aipatzen du, bata berak dakarrela eta bestea Juan de Samano Indietako Kontseiluko idazkariari utzi diola.

[Elkanok] erantzun zuen eta esan, Fernando de Magallanes bizi artean, lekuko honek ez duela ezer idatzi, ausartzen ez zelako, eta lekuko honek kapitain eta diruzain izendatu ondorengoa idatziz jasoa duela, eta, modu zabalean, [Juan de] Samanori emana diola, baina berak duela zati bat. ${ }^{42}$

Bigarren ebidentzia Gonzalo Fernandez de Oviedok ematen du. Elkano zuzenean ezagutzeaz gain, haren testua aurrean izan duela aitortzen du bere General y natural historia de las Indias (2011 [1535]: XX. liburua, 1 kapitulua, 15. or.) kronika-liburuan:

Johan Sebastian del Cano (aurrerago esango denez) Victoria ontzian Espainiara itzuli zen kapitainaren kontakizuna jarraitu dut, eta nik jarraitu dudan kontakizuna Maximiliano Transilvano izeneko heziketa oneko Zesarren idazkariak Salzeburgosko kardinalari idatzi zionaren ia bera da. ${ }^{43}$

Fernandez de Oviedoren pasartea froga sendoa da. Aurretik, Elkanok aitortzen du kontakizuna idatzi duela eta, kopia bat Sevillan utzi badu ere, bestea, zati bat gutxienez, Valladoliden duela. Bestetik, Elkanoren kontakizun idatzi hori bera erabili zuen Fernandez de Oviedok, Elkano hil ondoren, 1557an, mundu-bira kontatzeko. Eta Fernandez de Oviedok esaten digu, pasarte horretan bertan, berak aurrean duen idatzi hori dela, hain zuzen, Maximiliano Transilvanok ere erabili duena bere kontakizuna idazteko. Fernandez de Oviedok bi idatziak zituen aurrean, beraz, Elkanorena gaztelaniaz eta Transilvanorena latinez, eta biak konparatzeko aukera. Ondorioa hau da: Elkanoren kontakizu idatzia latinera itzuli zuela Transilvanok, ia hitzez hitz, «ia bera da». Eta, hortaz, «Transilvanorena» deitzen den kontakizuna, Magallaes hil ondorengo zati horretan behintzat, «Elkanorena» dela jatorriz.

42 «[Elkano] respondió y dijo que mientras fue vivo Fernando de Magallanes, este testigo no ha escrito cosa ninguna, porque no osaba, y después que a este testigo le eligiesen por capitán y tesorero lo que pasó lo tiene escrito y extendido lo tiene dado a [Juan de] Sámano, o parte de ello tiene en su poder.» (Bernal 2019a [1522]: 11-12)

43 «Yo he seguido la relación que Johan Sebastian del Cano me dió, que es aquel capitán que volvió a España con la nao Victoria (como adelante se dirá), é quasi la misma relación que yo sigo escribió el bien enseñado secretario de César, llamado Maximiliano Transilvano, al cardenal Salceburgense.» (Fernandez de Oviedo 2011 [1535]: XX. liburua, 1 kapitulua, 15 orria). 
Gainera, mundu-biraren zati horretaz diharduten Transilvanoren testua eta Fernandez de Oviedorena konparatzen baditugu gaur, demagun Borneo uharteko kontakizuna, bi testuen arteko parekotasunak nabariak dira. Fernandez de Oviedok Transilvano kopiatu zuela dirudi. Baina sumatu dezakegu, Fernandez de Oviedok aitortu duelako, parekotasuna datorrela biek Elkanoren testu bera jarraitzeagatik. Batean eta bestean ideia nagusiak berak dira, hain zuzen Elkanok bere eskuz idatzi zituenak.

Azkenik, Navarretek beste iturri berantiarragoa ere aipatzen du: ehun urte geroagoko Francisco de Seijas y Lobera izeneko historiagilea. Nonbait, hark ere Elkanoren idatzia ezagutu eta erabili duela baieztatzen omen baitu. Alegia, itxuraz, Elkanoren idatzi originala XVII. mendean ez zen oraindik galdu.

Horrek guztiak frogatzen du Elkanok mundu-biraren zati bat idatziz kontatuta utzi zuela. Autoreak (Elkanok) eta irakurri dutenek (Fernandez de Oviedok eta Seijas y Loberak) aitortzen badute, zergatik jarraituko dugu zalantzan jartzen Elkanok bidaiaren bere kontakizuna idatzi zuenik? Eta idatzi bazuen, nola liteke halako dokumentu garrantzitsu bat galdu izana? ${ }^{44}$

\subsection{Estiloa eta kronologia}

Transilvanoren testua bereziki esanguratsua denez, arreta berezia merezi du: zenbateraino da Elkanok idatzitako testuaren kopia zehatza?

Badakigu Transilvanok Elkanori zuzeneko testigantza entzun ziola, gutxienez behin. Zuzeneko lekukotzetan (pluralean) oinarritzen dela aipatzen du kontakizunaren hitzaurrean, baina izenez Elkano kapitaina aipatzen du soilik iturri gisa. Izenez bera bakarrik aipatzen du. Normala da hala izatea, batetik, Elkano zelako itzulitako ontzi bakarraren kapitaina eta ontziko bidaia-liburuen kargu izendatua (Magallaesena eta Elkanorena, bi kontakizunak galduak). Eta, bestetik, gure hipotesia indartzen duelako, Elkano bakarrik aipatzen du Elkanoren idatzia jarraitu duelako batez ere.

Gainera, Transilvanoren kontakizuna jarraian irakurtzen bada, Magallaes hil aurreko eta ondorengo zatiak, nabaria da batetik besterako estilo-aldaketa. Kontalaria aldatu balitz bezala, aurrena Magallaes eta ondoren Elkano. Aurrena arranditsu, politikoki zuzen eta ebanjelizatzaile eta ondoren zuzen, politikoki oker eta agendarik gabeko. Edonork egin dezake proba, liburu berean bi liburu gordetzen direla dirudi.

\footnotetext{
${ }^{44}$ Galdera nabaria da ea nola desagertu den halako dokumentu garrantzitsu bat, Elkanoren mundu-biraren kontakizuna, bidaia haren inguruko dokumentazio ikaragarria mantendu denean. Testurik garrantzitsuena galdu?
} 
Transilvanok hainbat iturri erabiliko zituen bere kontakizuna osatzeko, jakina, baina hain denbora gutxian, eta kontakizun guztia latinera itzuli beharrarekin, testigantzak pilatzen ere ezin izan zuen jardun. Horregatik, eta denbora gakoetako bat denez, gertakarien kronologia aurkeztuko dut.

Sanlukarrera irailaren 6an iritsi ziren, eta handik zaldun bat atera zen Valladolideko gortera, Elkanoren ohar edo gutunarekin. Zalduna irailaren 8a inguruan iritsiko zen Valladolidera, Elkano Sevillara bezala. Sevillan ongietorria jaso eta merkantzien neurketa eta banaketak egiteko egun batzuk behar izango zituzten. Ohean lo egin eta euren onera etortzen hasteko ere. Bitartean Erregeak Valladolidera deitu zituen Elkano eta honek aukeratutako bi. Bidaia zaldiz egin zezaketen, baina marinel gehiagok eta hiru molukarrek ere Erregea ezagutu nahi zutenez, bidaia beste nolabait egingo zutela jo dezakegu, zaldiz baino motelago. Valladoliderako bidaia egiteko hiru egunen ordez, gehiago beharko zituzten, beraz. Alegia, Elkano iraila amaieran iritsiko zen Valladolidera. Eta Erregearen harrera iraila bukaeran edo urriaren lehen egunetan izango zen.

Transilvanok urriaren 24 an bidali zuen bere latinezko kronika idatzia (Aguinagalde 2019b: 299). Beraz, hiru bat aste ${ }^{45}$ izango zituen Transilvano errege-idazkariak gehienera mundu-birari buruzko lehen kontakizuna, latinez, korrika eta presaka prestatzeko, aita santuarentzat propio egindako edizioa. Hortik aurrera, berehala zabalduko zen kontakizuna Europan zehar, 1523ko urtarrilean Kolonian (Alemanian) publikatu zenetik batez ere, edizio asko izan zituelako (Aguinagalde 2019b: 299).

\subsection{Bera ez bada, nor?}

Elkano ez bada Transilvanoren iturria, nor izan liteke? Izan ere, pentsatu behar da horrelako idatzi utopiko-kritiko bat (ikusiko dugunez: ez-inperialista, tolerantea, paganoa...) ezin etor daitekeela errege-idazkariarengandik. Ezin izan bazuen Transilvanok asmatu, Gattinararen morroiak, halako ideia iraultzaileak norbaiti entzun behar izan zizkion. Argi dago, baita ere, ezin izan zizkiola Magallaesi entzun, ez irakurri, Borneora iritsi aurretik hil zutelako. Gainera, Magallaesek ez zuen bat egiten ideia horiekin. Hortaz, ziurra da Sevillara iritsitako marinelen artetik iritsi zela errelato hori.

Dakigunez, hiru bidaiakide bakarrik bildu ziren erregearekin: Elkano, Albo eta Bustamante. Beraz, hiru horietako bat da ideia horien iturria. Demagun ez zela Elkano izan. Kasu horretan ere pentsatzekoa da, Alboren edo Bustamanteren kontakizuna balitz, Elkanoren onespenik gabe Transilvanok

45 Pentsa zeinen azkar idatzi zuen, Elkanori izena aldatzen baitio, Miguel jarrita. Presaren erroreak. 
ez ziela fidagarritasunik emango. Bera zen kapitaina eta berea zen azalpenen ardura. Elkanok ukatu egin izan balu Borneoko kontakizuna, Transilvanok ez zukeen jasoko. Beraz, gutxien-gutxienik badakigu Elkanok onartutako interpretazioa dela.

Dena den, badago arrazoirik kontakizun hori Elkanorena dela pentsatzeko. Albo pilotuaren itsasbidea ere iritsi zaigu. Oso zehatza da, teknikoa. Norabidea eta posizioa egunero jasotzea zen haren ardura; beraz, erregearen aurrean ibilbide nahasiaren auzi teknikoak argitzeko betekizuna zuen Albok. Bustamante, berriz, bidaiako 'medikua' zen, eta horregatik txopakoen gaixotasun eta heriotzez hitz egin beharko zuen. Gainera, Bustamante eta Elkanok harreman estua egin zuten. Bustamante Elkanoz fidatzen zela erakusten du bigarren espedizioan ere parte hartu izanak, Elkanoren barkuan. Bustamantek estimuan zuen Elkano kapitaina. Horregatik, hierarkiagatik, eta sintoniagatik, pentsatzekoa da erregeari bidaiaren nondik norakoak azaltzeaz Elkano arduratuko zela. Eta Transilvanok horrela aitortzen du Hitzaurrean ere, Elkano bakarrik aipatzen duenean (Albo eta Bustamante aipatu gabe utziz).

Horregatik guztiagatik, lekukotzak, estiloa eta kronologia kontuan hartuta, ondorioa da Transilvanok bidaiaren lehen zatia kontatzeko Magallaesek idatzitako liburuak erabili zituela (galdu direnak) eta bigarren zatia kontatzeko, berriz, Elkanok aurrez aurre esan ziona gehi bidaian zehar kapitain gisa idatzitakoa (hau ere galdua). Alegia, Transilvanok asmatua, sortua edo eraikia gutxi egongo dela testuan, eta ziurrenik laburpen-itzulpena izango dela ia kontakizun osoa.

\subsection{Elkanok egiaztatzen du munstrorik ez dagoela munduan}

Transilvanok lasaitua hartu zuen, agerikoa denez. Bere kronikaren lehen hitzak Herodoto eta Plinioren okerrak zuzentzeko erabiltzen ditu, haiek inoiz zapaldu gabeko hego-hemisferiotik pasatu zirelako Elkanoren ontziak eta euren begiz ikusiak ez zeukalako zerikusirik Herodoto edo Pliniok kontatzen dutenarekin. Etiopian ez dira trogloditak bizi eta kanela ez da Fenix hegaztiaren abian aurkitzen. Inportantea iruditzen zaio Transilvanori hasieratik hori argitzea, mundu ezagutu berrian ez dela munstrorik ageri. Mundubiraren meritu aipagarriena da, Transilvanoren iritziz, hegoaldetik bidaiatu izana, han munstro beldurgarririk ez dagoela frogatzeko:

Orain, bai, badakigu eta elezahartzat har ditzakegu eta ez egiazkotzat antzinako egileek idatzita utzitako hainbat; eta aurrean ditugunen esperientzien bitartez uka ditzakegula haiek. Nork sinetsiko du orain eta hemendik aurrera monoszelloak (edo estipadak) badirenik, edo espithameoak (pigmeoak) eta antzekoak, munstroak direnak gizaki bainoago, antzinako idazleek haiei buruz idatzi zuten arren, gaztelarrek eguerdiaren aurka nabigatuz eta mendebalderantz itzuliz, eta portugesek ekialderantz 
joanez, Kaprikornio tropikotik aurrera gradu asko pasatuta, hainbeste lur hain arraroak egiaztatu, aurkitu eta zapaldu ondoren? Eta, azkenik, orain ontzi honetan itzuli diren gure espainiar hauek, unibertso boilari itzulia eman ondoren, ibili duten guztian ez dutela sekula topatu, ez ikusi, ez jakiteko aukerarik izan, ez entzun, ez orain, ez aurreko denboretan, ez datozenetan, halako munstro-gizakirik? ${ }^{46}$ (Transilvano 1837 [1522]: 251)

Fantasiaz gizendutako mundu beldurgarria atzean uzten hasteko aukera ematen du Elkanoren etorrerak, eta europarrak Europan eusten zituen muga psikologikoa gainditze-bidean jarri zuen. Munduaren azpialdean ez da inor zerura 'erortzen', ez dago munstroz beteta eta hango gizakiak ez dira hankaz gora ibiltzen esku gainean. Lasai nabiga daiteke, beraz, itsaso haietatik, eta lasai egonkortu lurralde haietan guztietan, munstroen edo zeruen beldurrik gabe. Gizakia bakarra eta bera da munduko lur guztietan.

Pizkundean, autore klasikoen autoritatea berreskuratu zen garaian hain zuzen, antzinakoen deskribapenak asmatutako elezaharrak zirela frogatu zuen Elkanok. Bere begiz ikusi zuen, aurretik portugesek bezala, normal-normalak direla urruti-urrutiko lur haiek, zentzu horretan bederen, hango jendea bezalaxe. Amesgaiztorako baino amesteko aproposagoak.

\section{Borneo}

Transilvanoren testuaren bigarren zatia Elkanorena bada, orduan Borneoko kontakizuna Elkanok idatzitakoa da, haren berridazketa/itzulpena. Zentzu horretan, Transilvanoren/Elkanoren testua harrigarria da, batez ere, Borneoko uhartea deskribatzen duen pasarteagatik.

Eta zer ikusi zuen, bada, Elkanok Borneon? Europarrak ez direla zibilizazio bakarra, ezta hemengo bizimodua halabeharrezkoa ere. Europan baino hobeto bizi da jendea munduko bazter haietan? Itxura guztiz, horrelako galderak egiten zituen Getariako marinelak, testua irakurrita agerikoa baita herrialde haiek harrokeria ebanjelizatzailerik gabe begiratu zituela. Borneo uharteko jendartearen ohiturak deskribatzerakoan bisio utopiko zoragarria

\footnotetext{
46 «Antes tenemos agora conoscimiento, y de cierto creemos ser fabulosas y cosas no verdaderas las que los autores antiguos dejaron escriptas; y que con la experiencia de los presentes pueden aquellas ser reprobadas. Quien es el que creerá ya de aqui adelante que hay los Monoszellos (ó Stipadas), Spithameos (Pigmeos) y otros semejantes, que son mas monstruos que hombress, que los antiguos escriptores nos dejaron escripto que había, como veamos que los castellanos navegando contra el mediodia y volviendo hacia el poniente, y los portugueses yendo hácia el oriente pasando muchos grados adelante del trópico de Capricornio, hayan verificado, descubierto y hallado tantas y tan extrañas tierras; y finalmente, estos nuestros españoles que en esta nao agora volvieron, habiendo dado una vuelta al universo orbe, nunca hayan topado, visto ni podido saber ni menos oir en todo lo que han andado, que agora ni en tiempo alguno haya habido ni haya a los semejantes hombres monstruosos?» (Transilvano 1837 [1522]: 251)
} 
marrazten da. Elkano (bera bada) ez da ari Borneon ikusitakoa apaindurarik gabe deskribatzen, dakigunez hango errealitatea ez zelako hain txundigarria.

Harrigarria da Elkanok (bera bada) deskribatzen duen Borneo, eta ez dator bat gainerako txopakoek deskribatzen duten Borneorekin. Borneoko gertakariek ilun jarraitzen dute, zaila da han gertatua asmatzea. Transilvanoren (Elkanoren) kontakizunean, esaterako, ezer gertatu ez balitz bezala da. Bertako erregearekin hitz egin zuten, truke txiki batzuk egin zituzten eta aurrera jarraitu zuten. Ez da gehiago esaten Borneoko gertakariei buruz. Valladolideko galdeketan, ordea, azken galderan, argi dago zerbait gertatu zela, Elkanok Carvalhoren ustelkeria iradokitzen baitu: «Carvalho ikusi zuela erregearen salgaiak semeari eramaten, lehengusu baten bitartez, Bruney hirira ${ }^{47}$ (Bernal 2019a [1522]: 12). Pigafetta, Mafra eta Ayamonteren kontakizunetan ere Borneoko gertakariek garrantzia hartzen dute, baina bake-egoerak bainoago gerra-egoerak deskribatzen direlako. Gainera, azken hiru kontakizun luzeago horiek ere ez dira elkarren artean ondoegi ezkontzen. Gertakari anabasa kontraesanezkoa iradokitzen da. Batek ez daki lurreratutako Elkano eta beste zazpi lagunak 15 egunez bahituta izan zituzten, edo haien gogoz zeuden uhartean. Han zer egiten zuten ez da azaltzen. Elkano eta Gomez de Espinosa zergatik askatu zituzten ere, bertsioak daude. Dakiguna da Carvalho kapitainak zerbait gaizki egin behar izan zuela, Elkano eta Gomez de Espinosa uhartetik ontziratzean kapitain izendatu zutelako Elkano, Carvalhoren ordez. Eta Carvalhoren semea uhartean hil zela. Galderak sortzen dira erantzunak baino gehiago: errege mairuak (Siripada izeneko Rajak) agindu zuen Elkano askatu eta Carvalhoren semea hiltzea? Zergatik?

Pigafetta eta Mafrak diotenagatik Borneoko Siripada errege mairuak eta Luzongo erregeak inguruko herriak azpiratzen zituzten, jentilak izateagatik. Transilvanoren kontakizunean, berriz, jentilak bake-bakean bizi dira beti. Gertakarien trama argitzeko, batetik, bidaideen arteko gatazkak eta botereharremanak hobeto ulertu beharko genituzke, Elkano-Carvalho auzia esaterako, eta, bestetik, uharteko bertako gatazkak eta botere-harremanak, zeinak elkar-gurutzatzen diren.

\subsection{Elkanoren utopia: monarkia bakezalea, erlijio-askatasuna, eta beste hainbat ezusteko atsegin}

Borneo gatazka-leku izan zen bidaiarentzat. Horregatik, argi dago Elkano (bera bada) gehiago ari dela bere bisio utopikoa Borneon irudikatzen, gertakariak deskribatzen baino. Transilvanoren (Elkanoren) deskribapenak irakur-

47 «Que vio que el dicho Caravallo enviaba rescates a su hijo de la mercadería de Su Majestad con un primo suyo a la ciudad de Bruney.» (Bernal 2019a [1522]: 12) 
tzean, urrun-urruneko jendarte haiek ingurune idilikoan bizi zirela ematen $\mathrm{du}$, jendarte europarrekin alderatuta ez hain galduak, ez hain hondatuak; fanatismo eta handinahikeria gutxiagokoak, naturalagoak, onberagoak direlako oraindik.

Horrela irakurrita Elkanoren Borneo (1521) izango da, ziurrenik, basationa genero literarioaren lehenetariko testua, Rotterdamgo Erasmoren Eromenaren laudorioa (1994 [1511]) edo Thomas Mororen Utopia (1992 [1516]) liburuekin batera; hauen garaikidea ia. Batera aztertu beharko lirateke, Campanella, Bacon, Rousseau edo Voltaireren aurrekari nabarmen gisa, batez ere jakinik Europan erruz irakurri zela Transilvanoren bidaia-kronika eta, hortaz, pasarte hura.

\subsection{Errege gerrazaleak gerra-zelaira}

Edukiari arreta jarrita, badago monarkiari, edo zehatzago monarkia gerrazaleari (oroit Erasmo ere) egindako kritika gogorra. Errege ona bakezalea da, hain justu Karlos V.aren kontrakoa. Eta pentsa genezake Elkanok hori halaxe bota ziola, aurrez aurre, Karlos V.ari, Borneoko erregeak miresmenez deskribatu zituenean. Eta hemen merezi du geldialdia egitea, ikuskizuna irudikatzeko: Elkano Karlos V.ari Borneoko erregetza-modua azaltzen. Apartekoa, erabateko anomalia historikoa. Getariarra —orduan 35 urte inguru izango zituen-, apal-apal, 22 urteko Karlos V. gazteari irakaspena ematen errege onak nolakoa behar duen. Modu mingarrienean, gainera, basati ez-kristauak eredugarri jarrita. Ikustekoak izango ziren errege alemanaren eta gortesauen sumindura-aurpegiak. Eta, hala ere, munduari bira eman dionaren aurrean haiek ere isildu egin behar, dioena entzun, zintzo-zintzo, eta errege-idazkaria apunteak hartzen bazter batean.

Ezagutzaren balioa. Sekulako interesa dago Elkanok esan dezakeenaren inguruan, munduaren bestaldeko sekretuak ekar ditzakeelako. Elkanok zerbait badaki, interesekoa, mundua zeharkatu duelako eta bere begiekin ikusi duelako zabalera osoa. Horrek ezkutu gisa funtzionatzen du erregearen aurrean, beste inork esan ezin dizkionak esateko.

Izan ere, Elkanok dioenez (bera bada), Borneon herriak lortzen du erregea bakezale mantentzea beti, arautxo bat ezarriz: gerra pizteko erokeria egiten duen erregeak aurrena iritsi behar du gerra-zelaira, buru behar du, bermatzeko bera dela gerra horretan hiltzen lehena. Are gehiago, errege gerrazalea hil bitartean herriak ez du borrokarik egiten. Gerra maite duen erregea gerra horretan hiltzen dela ziurtatzen dute horrela, ez dela bizirik libratzen, eta soilik ondoren hasten dira "gupidagabe borrokan, euren askatasunaren alde eta euren lurretan ohikoa den moduko errege otzan eta bakezalea jartzeko». Ondorioz, jarraitzen du Elkanok, «herrialde haietan apenas dagoen gerrarik, 
erregeek jakin ongi dakitelako ez dutela gerratik bizirik ateratzeko inolako aukerarik» $^{48}$ (Transilvano 1837 [1522]: 275).

Europako monarkia gerrazaleek Pizkundeko humanisten artean sortzen zuten aurkako sentimendua gardentasun osoz jasotzen du Borneo uharteari buruzko kontakizunak. Eta giroa ere ordukoxea da, Erasmoren loraldi-garaikoa nolabait, XVI. mendearen hasieran 10-20 urteko barealdia ezagutu zuelako Europak, aurreko inkisizio-kolpe eta berehala etorriko ziren erlijio-gerra odoltsuen artean. Elkanok (bera bada) humanisten sintonia horretan aztertzen zituen dinamika politikoak.

\subsection{Errege ona, inguruko herriak bakean uzten dituena}

Hala ere, erregeari ematen dion aholku zuzenena eta argiena anti-inperialista da, inguruko herriak bakean uzteko adierazten dionean: «Borneo uharteko indio hauek oso oker eta txartzat dute erregeak desiratzea den baino jaun handiagoa izatea, eta bere jaurgoaren mugak zabaltzeko gosea» ${ }^{49}$ (Transilvano 1837 [1522]: 275). Elkano inperioaren morroia dela diotenek nola azalduko lukete pasarte hori? Ideia hori Elkanorena bada, eta oso posible da Elkanorena izatea, munduko herri guztiak elkar errespetatzera deitzen dituen ontzi-kapitain anti-inperialista agertzen da.

Hipotesi bat. Demagun Elkano ontzi-jabe gaztea hogeita gutxi urterekin merkatari lanetan zebilela eta gainerako ontzi-jabeak bezala erregeak Mediterraneoko gerretara behartu zuela. Jelbeseko gerrara akaso (1510). Elkanok jarri behar zuen barkua eta ordaindu txopakoa. Errege-aginduari ezin zaionez ezetzik esan, aukerarik gabe gerrara behartu zutela. Demagun orain Jelbeseko porrotaren ondorioz Elkanok galera izugarriak izan zituela, kideak agian, baina ontzia ziur, saldu behar izan zuelako. Hori hala gertatu bazen, Elkano inperiozale eta gerrazale irudikatzen duzue, edo alderantziz? Normalena litzateke, tentsio- eta galera-egoera horretan, Elkano erregearekin mintzea. Elkanok barkua galdu zuen, bere bizimodua. Eta ondoren askatasuna, barkua atzerritarrei saltzen harrapatu eta legez kanpo utzi zutelako. Hala izan balitz, haserrea eskatzen du. Hain justu testuan, lerroartean, nabari den erregearekiko haserre hori.

Jakitun naiz zaila dela beste Elkano bat irudikatzea, kasu honetan uste anti-inperialista sendoak dituena. Elkano inperialaren kontakizunean hezi

48 «E desta cabsa muy de raro tienen los desta isla guerra, porque los Reyes que suceden tienen conoscimiento y saben que ningund Rey que moviese en ella guerra escapó vivo de la batalla.» (Transilvano 1837 [1522]: 275)

49 «Tienen estos indios de la isla de Porné por cosa que es muy inicua y mala desear el Rey della ser mayor señor de lo que es, ni tener cobdicia de ensanchar los términos de su señorío.» (Transilvano 1837 [1522]: 275) 
gaituzte, eta Moluketako espedizioan inperioaren armadakide izan zen de facto. Baina haren pentsamendu eta ekintzak aztertzerakoan ebidentzia testualak gutxi dira, eta ditugunak hauek. Horregatik, aurrejuzgu interesatuengatik ez genuke hipotesirik gutxietsi behar. Eta behar besteko arreta eskaini beharko genioke Transilvanoren testuari, Elkanoren pentsaera arakatzeko ebidentzia kategoriara igota.

Nabaria iruditzen zait inperioarekiko desadostasunak agertzen eta distantziak markatzen ari dela Elkano, desadostasunak agertzeak dakartzan arrisku larrietatik babesteko, deskribapenaren atzean ezkutatzen badu ere kritika.

\subsection{Gerraren azalpen antropologikoa}

Badirudi borneotarrak ari direla haien erregeari kontuak eskatzen, baina beharbada Elkano ari zaio bereari zeharka. Eta ez dizkio txiki-txikiak ere esaten. Potolo askoak botatzen dizkio. Irakurri hau ere:

Inguruko herriei kalterik edo ondoezik ez eragiteko begiramen eta zaintza handia erakusten dute guztiek, are gehiago albo-uharteetako auzo-herriei kalterik batere ez egitekoa, eta askoz ere handiagoa atzerrikoei edo erromesei. ${ }^{50}$ (Transilvano 1837 [1522]: 275)

Gertukoak bakean utzi behar dira, baina batez ere urrunekoak. Hortxe dago ideia anti-inperialista, ezin hobeto formulatuta, eta bizimodu onarekin estuki lotuta. Bulkada inperialistak itotzen dituztelako bizi dira pozik eta bakean Borneon, zergatik ez Europan ere pozik eta bakean bizi?

Gainera, orokortu egiten du, psikologizatu nolabait, eta gaitz inperialistaren muinean botere-gosea eta handinahia topatzen ditu, berez-berez oso kristauak ere izan beharko ez luketen arimaren ajeak (oroit berriz ere Erasmo eta Moro). Botere-gose eta handinahiek sortzen dituzte dinamika gaiztoak eta gatazken gorakadak, garaiz hozten ez jakiteagatik gerra bihurtzen direnak. Gattinara errege-aholkulari eta inperiozale amorratua datorkigu gogora. Hura ere han zegoen, gortean, Elkanori entzuten?

Aipua luzea da, baina gako asko eman ditzake Elkanoren pentsaera ulertzeko, hitzon jabe bera dela frogatuko balitz edo onartuko bagenu:

Behin edo behin batzuek besteak mintzea gertatuko balitz, kaltetuek ederki zaintzen dute kalte egin dietenei jasotako mina baino gehiago ez eragitea. Eta gatazkek gora egin ez dezaten, bake-bidea lantzen dute, eta

50 «Tienen todos grand estudio y vigilancia en no se hacer ningund enojo ni molestia unos pueblos a otros, ni menos a los pueblos comarcanos de las otras islas circunvecinas, ni mucho menos a los estraños y peregrinos.» (Transilvano 1837 [1522]: 275) 
haien artean ez da aurkitzen ohore handiagorik edo goragoko dutenik aurrena eta oroz gain bake-asmoa izatea baino, eta bakea uxatzen duena ohorerik gabekotzat eta laidoztatzailetzat dute. Modu horretara, euren arteko desadostasunek eta gatazkek oso gutxi irauten dute. Eta haien artean ez dago ezer itsusiago edo deitoragarriagorik bakea eskatu zaion norbaitek hura ukatzea baino, eta ez duenean elkartasunera etorri nahi, aurretik iraindua izan denean ere, haren aurka egiten dute eta altxatzen dira, eta hiltzen dute eta suntsitu, pertsona anker eta gupidagabea izateagatik. Hortik dator uharteotan ia beti bake jarraitua izatea, lasaitasuna eta sosegua. Uharte horretako bizilagunen artean ez da lapurretarik, ez gizonen hilketarik. ${ }^{51}$ (Transilvano 1837 [1522]: 275-6)

Arazoa ez da soilik monarkia gerrazalea. Arazoa kulturala da, balioen mailakoa, Elkanoren iritziz (bera bada). Gatazkak kudeatzeko balio-saldo okerra daukagu Europan, gatazkak desegin beharrean batzuk eta besteak elkarren artean muturtzera eramaten gaituena. Eta balio-saldo hori ez dago giza naturan idatzita, ez dira nahitaezkoak, Borneon ezagutu direlako beste balio batzuk dituzten gizaki alaiak.

Jar gaitezen egoera politiko hartan. Karlos V.aren gorteak, 1522an, fronte asko zituen batera irekita: otomandarren oldarraldiak, Italiar penintsularen kontrola, Amerikako konkista, protestantismoaren gorakada... eta, arazo horietan guztietan, posizioak irabazteko irtenbide bakar bera proposatzen zuten: indarraren erabilera. Irudikatu orain ingurune politiko eta kultural horretan, otso-zulo horretan, Elkano Borneo uharte idilikoa deskribatzen.

Pisuzko arrazoiak ditugu Elkano Pizkundeko humanista utopikoen artean lerratzeko. Garaiko humanista utopikoek ez dute multzo homogeneoa osatzen, baina badituzte antzekotasunak ere, Elkanoren testuan (berea bada) nabari direnak. Nagusia jendartea eta moraltasuna lege, hezkuntza eta kulturaren sorkuntza gisa ulertzea. Tokian tokikoak eta moldagarriak dira, beraz. Beste ezaugarri komuna Europa «dekadente gerrazalea» arbuiatzea da, eta balio nagusiak askatasuna, tolerantzia eta adierazpen askatasuna izatea, landu daitezkeenak, bakean/merkataritzan arituko diren jendarte egonkorrak sortzeko. Horregatik ematen zieten forma utopikoa euren proposamen politikoei, ez zutelako den-

\footnotetext{
51 «E si alguna vez acaesce molestarse unos a otros, no curan los injuriados de hacer mas mal a los que los injuriaron de aquel que dellos recibieron. E porque las discordias no pasen adelante luego procuran de tratar de la paz, y no puede ser hallada entre ellos cosa mas gloriosa ni con que ellos mas se ensalcen y tengan por nobles que en se anteponer a demandar primero la paz, y tiénese por deshonrado y afrontado el que es prevenido a paz. E desta manera duran muy poco entre ellos las discordias y disensiones. E ninguna cosa hay entre ellos que sea tenido por mas fea o detestable que cuando veen que aquel a quien es demandada la paz la niega y no quiere venir a concordia aunque haya sido injuriado, y contra el tal conspiran y se levantan luego todos, y lo matan y destruyen como a persona cruel y sin piedad. E de aquí viene que cuasi en todo tiempo estan en continua paz, tranquilidad y sosiego. No hay latriocionios entre los moradores de aquesta isla, ni muertes de hombres.» (Transilvano 1837 [1522]: 275-6)
} 
boraldi baterako babeslekurik nahi, iraungo zuten herrialde berri egonkorrak baizik. Eta Elkano halakoxekoa deskribatzen ari dela dirudi.

\subsection{Paganismoaren defentsa}

Kristau-erreforma da Europako auzi kultural nagusia eta Borneon ere moral publikoa erlijioari lotuta aurkezten da. Uharteko bizilagunak paganoak dira, eguzkia eta ilargia gurtzen dituzte eta, nolabait horren ondorioz, zinez bakezaleak dira:

Uharteko indiar hauek jentilak dira sineskeran, eta jainko nagusitzat dituzte eguzkia eta ilargia. Eguzkiari buruz diote eguneko jainkoa dela, eta egunaren gaineko jaun gisa agintzen duela, eta ilargiari buruz gaueko jainkoa dela, eta gauaren gainean agintzen eta arautzen duela. (...) Uharte honetako jendea errukiaren eta justiziaren oso zalea da, eta batez ere bakea eta sosegua maite dituzte, eta liskar eta gerraren oso etsaiak eta deitoratzaileak dira. ${ }^{52}$ (Transilvano 1837 [1522]: 276)

Lotura egiten da erlijio politeistaren eta izaera bakezalearen artean. Ez da gehiago esaten, ez da analisi sakonagorik egiten, ez da azalpenik ematen. Ez dago interpretazio kultural edo teologikorik. Testua irakurrita ezin da urrunago joan, baina lotura eginda dago. Politeista paganoak bakezaleak dira.

Erlijio kristauaren dogmarik ere ez dute:

Jaio eta hil, besterik denik ukatzen dute, esanaz bizitza amaitzean amaitzen zaizkiola gizonari bere izatea eta zentzumenak, eta nola gizona ez zen deus jaio aurretik halaxe itzultzen dela ezerezera heriotzaren ondoren. ${ }^{53}$ (Transilvano 1837 [1522]: 276)

Hilezkortasunean ez dute federik paganoek, zigor eternoaren mehatxurik ere ez, beraz; eta, hala ere, pozik bizi dira, bakean, gatazkarik gabe, lapurretarik gabe, hilketarik gabe. Jendarte sano batek ez du fede-dogmarik behar.

Zaila da Elkano fededuna zenik ukatzea, hilondoko eta gutunetan kristau moduan idazten baitu. Gainera, ez dakit garai hartan euskal inguru-

\footnotetext{
52 «Son estos indios de la Isla de Porné en su creencia gentiles, y tienen por sus principales dioses al sol y a la luna. El sol dicen que es dios del día, y que sobre el día tiene su potestad y señoría, y que la luna es dios de la noche, y que su imperio y jurisdicción es sobre la noche. [...] Es la gente desta isla muy amadora de la piedad y de la justicia, y sobre todo de la paz y sosiego, y muy enemigos y detestadores de las disensiones y guerras.» (Transilvano 1837 [1522]: 276)

53 «No creen que hay mas que nascer y morir, diciendo que con la vida del hombre acaban su ser y sus sentidos, y que ansi como el hombre no era nada antes que fuese engendrado, ansi se vuelve en nada despues de la muerte.» (Transilvano 1837 [1522]: 276)
} 
nean sinkretismoa ere zabaldua zen (Barandiaran 1972; Garmendia 2007), edo disidentzia politikoa estigmatizatzeko trikimailu gisa erabiltzen zen soilik (Azurmendi 2019: 78-9). Gehiago jakin beharko genuke garaiko erlijio-sinesmenei buruz. Baina, hala eta guztiz ere, pentsatzekoa da euskalduna izateak lagundu egin ziola Elkanori sineste paganoak errazago onartzen. Bere jatorriak azal dezake agian jentilen aurrean ebanjelizatzailearen zalapartarik inoiz atera ez izana, eta guztiak sendatu beharraren ordez erlijio-tolerantzia aholkatzea.

Jainko asko izateak badu baita ere, nonbait, abantaila gehigarri bat gizonentzat bakarrik dena eta Elkanori (bera bada) atentzioa ematen diona: «Uharte honetako indioak manten ditzaketen bezainbeste emazterekin ezkontzen dira» (Transilvano 1837 [1522]: 276). ${ }^{54}$ Aberatsenek emazte gehiago izan ditzakete. Gizon-sari hori Borneon ez da bekatu. Bidaiatik itzuli eta Valladoliden egonkortzean, bigarren emakumea hartu zuen Elkanok. Europan 'indioak' basatitzat hartu ohi direnean, badirudi Elkanok (bera bada) ondo bizitzeko jarraitu beharreko ereduaren autoritatea aitortzen diela. Hango bizimodua zentzu askotan gustagarriago zaiola hemengoa baino XVI. mendeko marinelari.

Hitzon jabea Elkano dela pentsatzea zentzuzkoa da, eta hala izateak erabat aldatu beharko lituzke Elkanori buruz egin ohi diren interpretazioak. Besteak beste, eta dagokigunagatik, euskaldun bati inoiz jasotako lehen utopiaren aurrean geundekeelako. Eta filosofiaren ikuspegitik ez da munta txikikoa Elkano agertzea basati onaren eta egoera naturalaren gorazarre izango diren utopien genero modernoaren hastapenetan.

\subsection{Europari kritika}

Elkanori buruz aritzea 'eurozentrista' omen dela ere entzun dugu. Baina agian alderantziz da, garaiko Europari Elkanok egin zizkiolako kritikarik gogorrenak. Agian Elkano europar 'deszentratua' zen, munduko bazterretan topatu zituen zibilizazioek deszentratu zutelako. Bereziki esanguratsua da honako pasarte hau, Borneo atzean utzi eta Moluketara iritsi zenekoa, non Molukak eta Europa konparatzen diren:

Haien etxeak txabolatxo modukoak dira, oso baxuak eta txiroak, eta ez naiz hasiko bizi duten pobreziaren xehetasunik ematen, baina gureek diote Muluka uharteak oso apalak eta makurrak direla, eta bertako jendea oso zarpaila eta zikina, inolako hazkuntza edo poliziarik gabe, baina bi gauza direla soilik bikainak haien artean, jakitea komeni dena: bake eta

54 «Cásanse los indios desta isla con cuantas mugeres pueden mantener.» (Transilvano 1837 [1522]: 276) 
sosegu izugarria eta espezieria oparotasun ugaria; bietatik lehenak (bakea eta sosegua, munduan topa daitezkeen on guztien artean handiena eta onuragarriena dena) hilkorron gaizki ikaragarriak arroztu ditu hemengo gure tokietatik, Moluka haietara botata, eta hango jende baketsu hark darabil. Besteak, berriz, espezieriak, hertsatu egiten gaitu; batetik, gure lukurreria handiagatik eta, bestetik, gure gula aseezinagatik, mundu berri eta ezezagun hartara bila joanarazteko, hainbeste bizi-arrisku eta kaltebide pasatu behar izanda. ${ }^{55}$ (Transilvano 1837 [1522]: 279)

Hiru ideia daude pasartean. Bat. Moluketan pobreak dira, eta gizarte-antolakuntzarik ez daukate. Gogorra da han bizitzea. Bi. Europan, aldiz, gaizkia gailendu da eta, horregatik, ez da bakerik. Moluketara bota dugu bakea, han oraindik gaizkia nagusitu ez delako eta, horregatik, haiek bakean jarraitzen dute. Hiru: Europako zikoizkeriak eta aseezintasunak erokeriak egitera eramaten gaitu.

Europari egindako kritika gogorra da. Gailentasun ekonomikoa, soziala eta teknologikoa aitortzen dizkien arren, horrek ez du bizimodu hoberik ekarri, on guztietan nagusia, bakea, kanporatu egin dugulako. Europako gerra bakoitzak gaizkia gailendu dela erakusten du. Europa, Elkanoren begietan, gaizkia nagusitu den gerra-zelaia da: on guztietan gorena, bakea, galdu duena.

\subsection{Autokritika}

Itxura batean, autokritika ere nabaria da, bere espedizioa ere kritikatzen baitu. Europarrak Moluketara goaz zuhaixka usaindun bila, baina erotu garelako, zekenkeria eta diru-goseak itsututa. Itxuraz hori esaten ari da pasarte horretan. Arraroa da, ordea, hiru urte geroago Elkano bigarren aldiz abiatu zelako Moluketara iltze bila. Hipokrita zen? Ez zuen bere kritika sinesten? Bere burua 'zekentzat' zuen? Horregatik, ageriko autokritika honi buruz ohar bat egitea komeni da, interpretazio-ariketa sakontzea, badagoelako azaldu beharreko zerbait hor.

\footnotetext{
55 «Las casas que tienen son como unas chozuelas muy bajas y pobres, e por no me detener en todas las particularidades de su pobreza, dicen los nuestros que todas las cosas destos indios de las islas Molucas son muy humildes y de grand bajeza, y la gente muy puerca e sucia, sin ninguna crianza ni policía, y que solas dos cosas hay notables entre ellos, conviene a saber, grandísima paz y quietud y mucha abundancia de especiería, la una de las cuales (que es la paz y quietud, y el mayor y mas saludable bien de todos los que en este mundo hallarse pueden) ha desterrado destas nuestras partes la grandísima maldad de los mortales echándola en aquellas Molucas de que aquella gente pacífica usa. La otra empero que es la especiería nos constriñe lo uno por la grandísima avaricia que tenemos, y lo otro por nuestra insaciable gula a que hayamos de la ir a buscar en aquel incógnito y nuevo mundo, pasando por tantos peligros y discrímenes de la vida.» (Transilvano 1837 [1522]: 279)
} 
Nire interpretazioa da Elkanoren kritikak balio duela lehenengo espedizioa kritikatzeko, baina, aldi berean, eta hala eta guztiz ere, bigarren espedizioak erakargarri izaten jarraitzen duela, sari ekonomiko erraldoiagatik eta Elkanori egiten zaion aitortzagatik: kapitain eta kapitain nagusi izendatu zuten.

Hala ere, susmoa dut, posible dela espedizioari lotuta aipatzen diren 'lukurreria' eta 'gula aseezin' europar horrek hartzaile zehatzagoren bat izatea, Transilvanok jaso ez zuena. Izan ere, Borneotik Molukarako tartean agintaritza portugaldarra ordezkatu zuen Elkanok, eta orduan zuzendu zen espedizioaren misioa. Galduta zebiltzan eta Elkanok bideratu zituen? Ez, zehazki. Erregeak jarritako helburua espezia-bidea irekitzea zen, baina tartean Kapitainen helburu pertsonalak sartu ziren, bidaia nahaspilatu zutenak. Erregeak agindu zion Magallaesi topatzen zituen bi uharte nagusietako merkataritza-eskubideak biderkatuko zizkiola. ${ }^{56}$ Eta agian horrek azaltzen du zergatik Magallaes iparralderantz abiatu zen Ozeano Barean, zuzenean Moluka uhartetara (hegoaldera daude) zuzendu gabe. Eta agian horrek azaltzen ditu Magallaesek Filipinetako uharteetan egindako miatze guztiak, aliantzak eta gerrak. Eta agian horrek azaltzen ditu hura hiltzean, haren ordezko jarritako kapitain portugaldarrek emandako bueltak. Batez ere Carvalhok. Haientzat hartzeko bi uharte onenak aukeratzen zebiltzan?

Hori benetan hala bazen, eta Elkanok Erregeari hori hala kontatu bazion - bera kapitain izendatu bitartean noraezean bueltaka jardun zirela, kapitainen probetxurako uharte bila, eta berak zuzendu behar izan zuela norabidea Moluka uharteetara, espezia bila-, argi geratzen da aurreko kapitainen lukurreriak hamaika atsekabe sortu zizkiela. Gainera, posible da pentsatzea Transilvanori kontakizun hori ez zitzaiola Europan zabaltzeko egokia irudituko, eta erabaki zuela bere orokortasunean jasotzea, bereizketarik egin gabe espedizioko kapitain zekenen eta Elkanoren artean. Alegia, nire inpresioa da Elkano lukurreriaz eta anbizioak itsututako erokeriaz ari denean, Magallaes eta Carvalhoz ari dela. Kapitain portugaldarren zekenkeriagatik espedizioak ia porrot egin zuela adierazi ziola Erregeari eta idazkariak kontakizuna birformulatu zuela, zekenkeriaz orokorrean hitz eginez. Ikusita Elkano bigarren aldiz abiatu zela Moluketara eta bigarrenean kapi-

\footnotetext{
56 Karlos erregearekin Magallaes eta Falerok 1518ko martxoaren 22an sinatu zuten hitzarmenean irakurtzen da: «Bestetik, eskumen gehiago izan dezazuen, gure borondatea da horrela aurkitzen dituzuen uharteen artean, seitik gora balira, eta lehenengo seirak guretzat aukeratu ondoren, gainerakoen artean, haietatik bi izendatu ditzazuela, eta gastuak kitatuta bertan guretzat garbi ateratzen diren ondasun, errenta-interes eta eskubideen bostena zuentzat izan dadila» (Bernal 2019c [1518]: 3) («Otrosi, por vos hacer mas merced, es nuestra voluntad que de las islas que así descubriéreis, si pasaren de seis, habiendo primero escogido para Nos las seis, de las otras que restaren, podáis vosotros señalar dos de ellas, de las cuales hayáis y llevéis la quincena parte de todo el provecho e interés de renta y derechos que Nos de ellas hubiéremos limpio, sacando las costas que se hicieron»).
} 
tain jarri zuela Erregeak, zentzuzkoa iruditzen zait pasarte horretako 'autokritika' horrela irakurtzea.

\subsection{Egin liteke estudio bat?}

Borneon bakean eta pozik bizi badira, zergatik ezin gara Europan berdin bizi? Elkanok (bera bada) Borneon irudikatu zituen bere herrian izan nahi zituzkeen hainbat bertute, askatasun eta giza harreman. Asko sinesgogor eta eszeptiko agertuko dira interpretazio honekin, itzulia ematen baitio Elkanori buruzko interpretazio inperial hegemonikoari. Horregatik, Elkanori buruz ikertzen jarraitu behar da.

Sen onari jarraituta, eta ziur dakigunera mugatuta, ondo justifikatzen da ondorioztatzea Transilvanoren idatzian Elkano ari dela hizketan. Bere hitzak eta ideiak direla. Hala ere, ez dago argudio erabatekorik eta oraindik asko dago ezagutzeke. Ikerketa bat baino gehiago merezi du Elkanok. Jaso dugun Elkano inperiala, morroia eta esanekoa, zapaltzailea eta konkistatzailea desmuntatzen hasteko egokiena protagonisten galdutako kontakizunak noizbait aurkitzea litzateke. Horren zain geratu gabe, ordea, Transilvanoren eta Fernandez de Oviedoren atalak xeheago aztertu beharko lirateke, filosofikoki, Mororen eta Erasmoren testu garaikideekin multzoan, haiekin batera Elkano ere Pizkundeko humanista utopiko gisa ezaugarritu dezakegun erabakitzeko.

\section{Humanista, bakezalea, fidagarria}

Behin honaino iritsita, zer esan dezakegu bada Elkanoz? Pertsona bitxia dela, Juan Sebastian, trokeletik apartekoa. Getariako marinel-merkataria, goimailakoa, profesionalki fenomeno bat, Moluketako espeziak Europan salduz ahalik eta azkarren sendiaren ziurtasun ekonomikoa bermatu nahi zuena. Gogorretan gogorrena oinazeen aurrean. Eta talde-liderra (Otazu eta Diaz de Durana 2008; Zulaika 2019). Euskaldunekin herri-leialtasunak gordetzen zituena, zein klase-leialtasunak txopakoekin. Horregatik guztiagatik, nire inpresioa da batez ere fidagarria zela Elkano. Ezagutzen zutenek behin eta berriz berresten ziotelako konfiantza, eta muturreraino eramateko prest agertzen dira, egoera zailenetan eta proiektu arriskutsuenetan. Eta guk ere inpresio bera hartzen dugu bere idatziak eta erantzunak irakurtzen ditugunean, fidatzekoa zela, profesional bikaina eta balio sendokoa.

Bere pentsaera aztertuta, berriz, Elkano Pizkundeko humanista utopiko gisa agertzen dela erakusten saiatu naiz: erlijio politeisten balioespen positiboa egiten duena, Europako gainbehera morala salatzen duena eta, batez ere, monarkia gerrazalea gaitzestera iristen dena. Giza natura moldagarriaren 
teoriatxoa ere proposatzen du gertuko eta urruneko kulturak, batzuk eta besteak hain ezberdinak, behatuz eta konparatuz. Merkataritza soseguz egiteko behar den bake-egoerak ekartzeko gatazken konponbiderako proposamenak ere egiten ditu. Eta, inperioaren ahoan bizi den arren, bereziki arbuiatzen ditu handinahia eta handitzeko nahia gatazka-iturri alferreko gisa.

Praktika politikoen ikuspegitik, erregearen agindupean jarri zen batzuetan, baina desobeditu izan zuen, behar izan zuenean. Bazekien inperioarekin kolaboratzen, komeni zitzaion neurrian, baina jasotako aginduen edo indarreko legeen gainetik bizia eta arrazoia lehenesten zituen, men ez egiteraino. Erdi Aro kutsua oraindik galdu ez duen garairako, handia da munduari bira ematea, eta handiagoa, akaso, plebeioa izanik kapitain jarri eta Inperioari desobeditzen asmatzea.

Horregatik guztiagatik, uste dut munduari kontatzen jarraitu beharko genukeela herrien arteko bakezko harremanetan sinesten zuen euskalduna zela Juan Sebastian, Elkanotarra. Getarian jaioa, sekula izan den itsasgizon gogoangarriena, munduaren biribiltasuna lehen aldiz inguratu zuena Koroa erasokorrenen gainean ere maisuki nabigatuz.

\section{Erreferentziak}

Aguinagalde, Borja. 2016. «¿Qué sabemos realmente sobre Juan Sebastián de Elcano?». In Manuel Parodi (arg.), Actas del I Congreso Internacional sobre la I vuelta al mundo. Sanlucar de Barrameda, Sevilla, 25-37.

Aguinagalde, Borja. 2017. «El archivo personal de Juan Sebastián de Elcano (14871526)». In Manuel Parodi (arg.), Actas del II Congreso Internacional sobre la I vuelta al mundo. Sanlucar de Barrameda, Sevilla, 65-93.

Aguinagalde, Borja. 2018. «Juan Sebastián de Elcano. El marino que guardaba un archivo». San Telmo Museoa, "Ciclo Elcano» hitzaldia, apirilaren 4an. Non: https://www.youtube.com/watch?v=TPV3ZiNwDxA

Aguinagalde, Borja. 2019a. «Las dos 'cartas' que escribió el capitán Juan Sebastián de Elcano a su regreso». In Ravina et al., La primera vuelta al mundo. Edición conmemorativa del $V$ centenario del viaje de Magallanes y Elcano, 1519-1522. Madril: Taverna literaria, 145-176.

Aguinagalde, Borja. 2019b. «El capitán Juan Sebastián, o Elcano en su entorno. Guetaria, la cirnunnavegación y la corte del emperador». In Revista General de Marina, abuztua-iraila: 287-302. ISSN: 2530-2361.

Angleria, Pedro Martir. 1494-1525. Décadas del Nuevo Mundo. Erabilitako edizioa: Buenos Aires: Editorial Bajel, 2012.

Ayamonte, Martin. 1522ko otsailaren 5a. Relación de Martín de Ayamonte. Non: https:// www.rutaelcano.com/martin-ayamonte

AZURMENDI, Joxe. 2015. «Sarrionandia: nazioaren kontzeptua behelaino artean». Jakin 207: 11-65.

BARANDIARAn, Joxe Migel. 1972. Diccionario ilustrado de mitología vasca. Bilbo: Editorial de la gran enciclopedia vasca. 
BERNAL, Cristobal. 2019a. Interrogatorio tras la aventura (18-X-1522). Sevilla: Patronato V centenario. Non: http://sevilla.2019-2022.org/wp-content/uploads/2016/03/11. ICSevilla2019_Interrogatorio-tras-la-aventura-s14.pdf

BERnAL, Cristobal. 2019b. Información hecha a instancias de Fernando de Magallanes y Relación de la Gente que llevó al descubrimiento de la Especiería o Moluco. Sevilla: Patronato V centenario. Non: http://sevilla.2019-2022.org/wp-content/ uploads/2016/03/5.ICSevilla2019_Relaci\%C3\%B3n-de-la-gente-que-llev\%C3\%B3al-descubrimiento-de-la-Especier\%C3\%ADa-n14.pdf

Bernal, Cristobal. 2019c. Asiento y Capitulación hecha con Fernando de Magallanes y el bachiller Ruy de Falero. Sevilla: Patronato V centenario. Non: http://sevilla.20192022.org/wp-content/uploads/2016/03/3.ICSevilla2019_Asiento-y-capitulacionescon-Magallanes-y-Falero-o14.pdf

Cotarelo, Juan. 1861. Biografía de Juan Sebastián de Elcano. Tolosa: Imprenta de la provincia.

ElCANO, Juan Sebastian et al. 2018. La primera vuelta al mundo. Juan Sebastián de Elcano, Antonio Pigafetta, Maximiliano Transilvano, Francisco Albo, Ginés de Mafra y otros. Madril: Miraguano Ediciones.

ElorzA, Manuel. 1976. Juan Sebastián de Elcano. Síntesis ilustrada. Edición bilingüe. Donostia: Cartoné.

ERASMO, Rotterdamgo. 1511. Stultitiae Laus. Euskarazko itzulpena: Julen Kaltzada. 1994. Eromenaren laudorioa. Bilbo: Klasikoak.

FERnÁNDEZ DE NAVARRETE, Martín. 1837. Colección de los viages y descubrimientos que hicieron por mar los españoles desde fines del siglo XV. Madril: Imp. Nacional.

Fernández de Navarrete, Eustaquio. 1872. Historia de Juan Sebastián del Cano. Gasteiz: Imprenta de los hijos de Manteli.

FERNÁNDEZ DE Oviedo, Gonzalo. 1535. Historia general y natural de las Indias. Libro XX. Lehen edizio osoa: 1853, Madril: Real Academia de la Historia. Berrargitaratua: 2011, Alicante: Biblioteca Virtual Miguel de Cervantes. Non: http:// www.cervantesvirtual.com/obra-visor/historia-general-y-natural-de-las-indiasislas-y-tierrafirme-del-mar-oceano-tomo-primero-de-la-segunda-parte-segundo-dela-obra--0/html/

GARMENDiA, Juan. 2007. Conjuros no siempre ortodoxos. Donostia: Eusko Ikaskuntza.

GreEngrass, Mark. 2013. La destrucción de la cristiandad 1517-1648. Bartzelona: Ediciones de Pasado y Presente, 2015.

GuicCIARDINI, Francesco. 1537. Historia d'Italia. Venecia: Nicolò Beuilacqua. Erabilitako edizioa: Di Agostini, 2013, Roma: UTET.

LAS CASAS, Bartolome. 1522. Brevísima relación de la destrucción de las Indias. Sevilla. Erabilitako edizioa: 1999, Madril: Castalia.

MAZÓN, Tomás. 2020a. Elcano. Madril: Ediciones Encuentro.

MAzón, Tomás. 2020b. «Viaje a la historia». San Telmo Museoa, «Ciclo Elcano» hitzaldia, urtarrilaren 16an. Non: https://www.youtube.com/watch?v=5JeHicQ$5 \mathrm{~T} 4 \& \mathrm{t}=278 \mathrm{~s}$

Moro, Tomas. 1516. Utopia. Euskarazko itzulpena: Piarres Charriton. 1992. Utopia. Bilbo: Klasikoak.

Muthu, Sankar. 2003. Enlightenment Against Empire. Princeton: PUP.

Otazu, Alfonso eta José Ramón Diaz De DuRana. 2008. El espíritu emprendedor de los vascos. Madril: Silex. 
PAgDen, Anthony. 2014. «Conquest and the Just War: The "School of Salamanca" and the 'Affair of the Indies'». In Sankar Muthu (arg.), Empire and Modern Political Thought. Cambridge: CUP, 30-60.

PigafetTA, Antonio. 1522. La primera vuelta al mundo. Madril: Alianza Editorial, 2019.

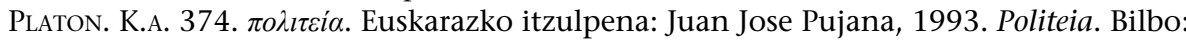
Klasikoak.

Ramos, Demetrio. 1990. «Influencia de los descubrimientos en la ideología europea. El origen de 'la utopía', como fruto del descubrimiento colombino». Anales de Historia Contemporánea 8: 27-43.

Real Academia De la Historia. 2019. «Informe de la Real Academia de la Historia sobre la primera circunnavegación a la tierra». 2019, martxoak 1. https://www.rah.es/ wp-content/uploads/2019/03/Informe-de-la-Real-Academia-de-la-Historia-sobrela-Primera-Circunnavegacion-a-la-tierra__.pdf

Solorzano, Juan. 1647. Política Indiana. Tomo I. Erabilitako edizioa: Tomás y Valiente, Francisco, 1996, Madril: Biblioteca Castro.

ZweIG, Stefan. 1938. Magellan: der Mann und Seine Tat. Gaztelaniazko itzulpena: Magallanes: La aventura más audaz de la humanidad. 1945. Buenos Aires: Editorial Claridad.

Transilvano, Maximiliano. 1522. Relación de Maximiliano Transilvano. Non: Fernández de Navarrete, Martín, Colección de los viages y descubrimientos que hicieron por mar los españoles. IV liburukia. 1837. URL: https://docs.wixstatic.com/ugd/9a00c3_ f2b26c05d411449386fbb924e2b552bf.pdf

ZulaIKA, Daniel. 2019. Elcano, los vascos y la primera vuelta al mundo. Getaria: Mundubira 500 Elkano Fundazioa. 